\title{
The link between technology transfer and international extension of university patents: evidence from Spain
}

\author{
Catalina Martinez* \\ Institute of Public Goods and Policies (CSIC-IPP), Albasanz 26-28, 28037 Madrid, Spain \\ Lydia Bares \\ Department General Economics, University of Cadiz, Glorieta Carlos Cano s.n. 11002 Cadiz, \\ Spain
}

\begin{abstract}
This is a pre-copy-editing, author-produced PDF of an article accepted for publication in Science and Public Policy following peer review. The definitive publisher-authenticated version [Martínez, C. and Bares, L. 2018. The link between technology transfer and international extension of university patents: evidence from Spain. Science and Public Policy, 45, 6: 827-842] is available online at https://doi.org/10.1093/scipol/scy008
\end{abstract}

\begin{abstract}
The aim of this paper is to shed light on the decision making process at university technology transfer offices and show that the last steps in the process of international patent extension, when costs step up, tend to be only taken conditional on the existence of a licensing agreement. This information has so far been underexploited by policy makers and innovation scholars in search of innovation indicators. We argue that the number of international patent families filed by a university can be used as a rough indicator of technology transfer activity mediated through patents, especially in the context of tight public university budgets and national patent systems with fee reductions for universities. To support our argument, we review qualitative information from interviews at technology transfer offices, regulations and internal statutes from a selection of Spanish universities and present a statistical analysis of the relation between patent internationalisation and licensing.
\end{abstract}

Keywords: university patenting; internationalisation; patent families; licensing; Spain.

JEL: L38; O32; O34; C25

*Corresponding author: Catalina Martinez, Institute of Public Goods and Policies (CSIC-IPP) Albasanz 26-28, 28037 Madrid, Spain. Tel: +34 916022543. Fax: +34 916022971. Email: catalina.martinez@csic.es 


\section{Introduction}

The past decades have seen a generalised increase in the number of patent applications filed by universities in almost all countries. ${ }^{1}$ Although at the beginning such growth was more strongly felt in the United States, it soon became a worldwide phenomenon. Many contributing factors can be cited, such as increasing public R\&D expenditure (Coupe 2003; Payne and Siow 2003; Azagra et al 2006a; Acosta et al 2009); the role of public science in the emergence of the biotechnology sector and the rise of drug and medical patents (Henderson et al 1998; Zucker et al 1998); increasing researchers' incentives to patent in terms of royalty shares (Lach and Schankerman 2008; Arqué Castells et al 2016) and other institutional support and proactive IP regulations to promote patent ownership of academic inventions at universities (OECD 2003; Lissoni and Montobbio 2015, Della Malva et al 2013; Del Barrio-Castro and Garcia-Quevedo 2009; GarciaQuevedo 2010; Arque-Castells et al 2016). ${ }^{2}$

Within the extensive literature on the determinants and impact of university patenting, early studies were critical about the impact of pro-patenting policies at universities and argued that a large part of the observed increase in university patenting after the BayhDole Act in the United States in 1980 had been caused by low-value filings, proxied by number of citations received, as well as by the entry of inexperienced institutions (Henderson et al, 1998). More recent studies have warned about relying too much on citations to determine the impact of university patenting, as compared to business patents, given that university patents take longer to be cited because of their more fundamental nature (Sampat et al, 2003; Sterzi, 2013). In general, innovation policy scholars call for further research to better grasp the impact of university patents and explore whether patents are an effective means to transfer technology to the private

\footnotetext{
${ }^{1}$ We will use the term 'university patenting' throughout the paper to refer to patents filed by universities or university-affiliated institutions. They are a subset of the broader term 'academic patenting', defined as patents invented by university professors but not necessarily filed universities (see Lissoni 2013 for an overview and for Spain, see Martinez, Azagra and Maraut 2013 and Martinez and Maraut 2014).

${ }^{2}$ Concerns about potential conflicts of interest have also been echoed in the literature, but the empirical evidence available is either inconclusive or points at lack of negative effects. These concerns relate to threats from patents to scientific progress due to restrictions to disclosure and data sharing or to the use of research tools; changes in the direction of research to the detriment of more basic projects; substitution effect between patents and publications and decline of their quality over time; and finally, potential threats to the teaching mission of universities, with possible decline in students' publications and informal learning (Walsh, Cho, Cohen 2005; Mowery et al, 2004; Baldini, 2008; Breschi et al, 2008; Thursby and Thursby 2007; Franzoni and Scellato, 2011; Geuna and Nesta, 2006; Azagra Caro et al, 2003; Saragossi and van Pottelsberghe de la Potterie, 2003; Crespi et al, 2005; Lissoni et al, 2008; Lissoni et al, 2013).
} 
sector and society in general. An agenda that is fraught with difficulties given that information on university patent licensing and commercialisation is rarely available at the patent level.

The aim of this paper is to contribute to this line of research by assessing to what extent we can take advantage of the close links between internationalisation and commercialisation of university patents to use the former as a proxy for the latter. A question that is likely to be more relevant in the context of tight budgets where technology transfer offices at public universities are under pressure to decide which patents are worth incurring additional procedural costs and which ones they would rather abandon or keep national. ${ }^{3}$

Considering that one important rationale for university patenting, and the argument that prevailed in the debates towards the enactment of the Bayh Dole Act in the United States, is the so-called commercialisation theory (Lemley 2008) ${ }^{4}$, our work stresses the need to know more about the characteristics of university patents that are eventually licensed to industry and use such information to build new innovation indicators. ${ }^{5}$ Following the implementation of national policies emulating the spirit of the Bayh Dole Act (Mowery and Sampat 2005, Geuna and Rossi 2011), many European countries have seen a boom in university patenting in the past decades. How many of those patented inventions reached the market is an empirical question not always easy to answer as data on commercialized university patents is often gathered through one-off surveys offering results on relative small samples or through annual surveys performed by TTO networks that only publish aggregate results. We argue that extensions of university patent filings to foreign patent offices are a timely and publicly available source of information that could be used by policy makers and innovation scholars to better understand the role of technology transfer offices and the university patenting decision making process.

\footnotetext{
${ }^{3}$ In the United States, as noted Lemley (2008, p.616), "exclusive licenses often pay the cost of patent prosecution, a relatively small savings but an immediate one that impacts the TTO bottom line. The result is that an overwhelmingly majority of university patents are exclusive".

4 "Unlike the classic incentive theory, commercialisation theory argues that it is not so much the act of invention, but instead the act of turning that invention into a marketable product that requires investment and therefore the exclusion of competition. According to this theory, university inventions will languish and not be commercialized unless we give someone (initially the university, but presumably eventually a private company to which the right is licensed or transferred) control over the invention, and therefore incentive to invest in developing and marketing it." Lemley (2008, p.621)

${ }^{5}$ Keeping in mind that university technology transfer can happen through other channels as well, not only through licensing university-owned patents (Ramos-Vielba et al 2010).
} 
We rely on information about Spanish universities and focus on the region of Andalusia as a case study. Andalusia, the second largest Spanish autonomous community and has been for a long time one of the Southern European regions classified as less-favoured by the European Commission. The case of Spain is interesting because, since 2001, public universities are exempt from paying filing and maintenance fees at the Spanish Patent and Trademark Office (OEPM) and according to the Patent Law of 1986 (in force until a new patent law entered into force in April 2017) Spanish patents could be granted based solely on formal requirements, without formal examination, unless the applicant decided otherwise and paid an extra fee (Represa et al 2005; Martinez 2009). ${ }^{6}$ Therefore, the Spanish national patent system did not really provide incentives for universities to filter out their lowest value patents for three decades. Universities could arguably file national patents for all the inventions disclosed by their staff and obtain national protection at almost no cost. ${ }^{7}$ The screening process effectively started twelve months from the priority filing, if the decision to go international was eventually taken, and then patenting costs increased gradually (Martinez 2011).

We argue that generally only patents licensed to third parties or with good prospects of being exploited internally by technology partners, university spin-offs or private coapplicants were worth incurring the additional cost and hurdles of seeking international protection in foreign countries. The first step in the international extension of patents was generally to file an international Patent Cooperation Treaty (PCT) application with the World Intellectual Property Organisation (WIPO). Taking the PCT route served to buy time and keep open the option of seeking protection abroad for an additional period of time: 30 months with the PCT procedure instead of 12 months with direct foreign filings. ${ }^{8}$ Only patents that were expected to be successfully transferred technology to the

\footnotetext{
${ }^{6}$ Universities nevertheless were also exempted from paying this extra fee. An increasing share of university patents opted for substantial examination over the years (see footnote 37). A new Spanish Patent Law was approved in 2015 and entered into force in April 2017 (Patent Law 24/2015, of 24/07/2015). This new law ended with the dual patent granting system, so that all patent applications filed at OEPM from then onwards had to go through substantive examination of novelty and inventive step (Article

39).https://www.oepm.es/export/sites/oepm/comun/documentos_relacionados/Noticias/2015/2015_07_27 _Nueva_Ley_de_Patentes_BOE-A-2015-8328.pdf

7 The enforcement of such protection in court would have been more costly and less certain, but that is another story.

${ }^{8}$ The PCT procedure requires applications to enter the national phase in the designated patent offices and incur translation and additional filing fees in each one of the selected offices 30 months from the date of priority. The date of priority is the date of the earliest patent application of an invention, often filed at the country of residence of the applicant (OECD 2009).
} 
private sector or judged of being of sufficiently high value would be worth to initiate internationalisation procedures via PCT and often only those with a signed licensed agreement would continue through the national phase. ${ }^{9}$

We rely on data about patent filings and different phases of international protection as well as information about the university decision making process from interviews to technology transfer managers from the sampled universities, internal regulations at the institutional level and supporting policies at the national and regional level. Information on patent families filed by public universities comes from the OEPM website and from the European Patent Office (EPO) Worldwide Patent Statistics Database (Patstat). In turn, information on technology transfer at the patent level comes from the Annual Reports of Andalusian Plan for Research, Development and Innovation, which for a few years (between 2003 and 2009 only) published information on the licensing agreements signed by the regional public universities and identified the patents involved in those agreements.

The paper is organized as follows. Section 2 presents a brief literature review and background for the analysis presented later. Section 3 reviews the legal framework for university patenting in Spain and some aggregate statistics for all Spanish public universities, and Section 4 presents an in-depth case study of technology transfer and internationalisation of patents in the nine public universities of Andalusia, where we summarise information from interviews with managers at the technology transfer offices of the sampled universities and present the results from our statistical analysis at the patent level. Section 5 concludes.

\footnotetext{
${ }^{9}$ Spain was one of the signatory countries of the first international treaty on patent protection, the Paris Convention (1983) since its inception. The Paris Convention made possible to file a patent application in other signatory countries claiming the priority date of the first application, with the restriction of 12 months from first filing (Martinez 2011). In 1989, Spain signed the Patent Cooperation Treaty (PCT), managed by the World Intellectual Property Organization (WIPO). The PCT procedure enables to obtain patent rights in 152 countries (as of October 2017) by filing a single international application at the OEPM. After the priority filing, the applicant has up to 30 months to enter the national phase, which implies that the applicant can postpone the payment of national entry fees and translation costs until having more information about the value of the patent (OCDE, 2009). According to the European Patent Convention (EPC), applicants can enter the PCT national phase either by filing directly at the EPC member national patent office or at the European Patent Office. The latter case is also known as 'entering the regional phase at EPO', but for the sake of simplicity we will include it in the term 'entering the national phase'.
} 


\section{Literature review and background}

Patent internationalisation, understood as the decision to extend patenting protection beyond the country of origin of the applicant, is a widely accepted indicator of patent value. It reflects high expected commercial value from the point of view of the patent owner, at least above the large costs entailed (Dernis and Khan 2004; Martinez 2011; Frietsch et al 2009; Squicciarini et al 2013). The positive relation between patent value and family size - the number of countries where patent protection is sought for a given invention - is well documented in the literature (e.g. Putnam 1996; Guellec and van Pottelsberghe 2001; Dernis and Kahn 2004; Frietsch and Schmoch 2010; Martinez 2011; van Zeebroeck 2011), but most studies focus on patents filed by firms.

We contribute to the literature by focusing on university patents. We offer novel quantitative and qualitative evidence in support of interpreting international patent families filed by public universities as a rough indicator of university technology transfer activity. We follow previous studies showing that patent filing routes are stable indicators of patent value (van Zeebroeck and van Pottelsbergue 2008) and go one step further by exploiting differences in the determinants of international and national university patents (Azagra et al 2006b).

Patent protection is generally only worth extending abroad if expected benefits exceed the extra costs incurred in the process, both in public research institutions and in private companies. The main difference between private and public patent owners is that the latter are essentially 'non practicing entities' (Lemley 2008; Martinez and Sterzi 2016), in other words, that patents filed by universities and other public research organisations can only be exploited, and revenues can only be obtained from them, if licensed or transferred to third parties (understood broadly to comprise also university spinoffs) with capacity to exploit the invention. Thus, for universities and their TTOs, successful patent management equals exploitation of the patent by a third party, generally through a licensing agreement (Fernández-Sánchez and Muñoz-Orellana 2016), but only a small share of the patents filed by a university are eventually licensed, and only a few of those bring substantial returns in terms of royalties to the university (Thursby and Thursby 2003).

Public research organisations and universities can initiate the process of international patent protection when the TTO and other actors involved in the decision making 
process consider that the expected patent value exceeds the cost. This cost is lower at the first stages of the process and can increase steeply after 30 months from the earliest filing (called the priority filing, generally made at the domestic office of the applicant) if the applicant takes the PCT route and once it is finished decides to seek protection in multiple patent offices paying the corresponding national fees, attorney and translation costs.

As described in two thorough studies of the decision making process at TTOs by Fernández-Sánchez (2014) and Fernández-Sánchez and Muñoz-Orellana (2016) ${ }^{10}$, the key is to be able to value the exploitation potential of the technologies generated at the university at each of the stages of its development, as a function of the information available at each step of the process in a context that is generally characterized by high uncertainty and low availability of resources. They list a number of factors that can affect such process: i) economic (limited budget, lack of culture of the research groups to obtain the necessary funds to protect their inventions); ii) technological; iii) commercial (potential economic interest, expressions of interest from possible licensees); iv) legal and v) specific to the researchers and other actors involved (research group, experience, expectations, leadership, conflicts). They group all these factors into four different dimensions related to technological features of the inventions, economic aspects of the patenting process, legal framework and, lastly, managerial and institutional features and propose TTOs to rely on a qualitative valuation method ${ }^{11}$ taking them into account, using all possible information available at each step in the process $^{12}$ and stressing that decisions mainly take place in the first 30 months from the date of priority.

\footnotetext{
${ }^{10} \mathrm{We}$ are very grateful to Rebeca Fernández Sánchez from the TTO of the University of Granada for helpful discussions and for sharing her work with us (Fernández-Sánchez 2014; Fernández-Sánchez and Muñoz-Orellana 2016).

11 Kamiyama et al (2006) divide the different patent valuation approaches proposed by experts into qualitative and quantitative methods. First, qualitative valuation methods "attempt rating and scoring patents based on factors such as the strength and breadth of patent rights and their legal certainty. These methods have often been used for the purpose of internal patent management, due to its relative simplicity compared to quantitative valuation methods." (p.25). Second, quantitative valuation methods "attempt to calculate the monetary value of the patents, including three major approaches: the cost approach, market approach and income approach (Smith and Parr 2000), each of which is also used to value fixed assets and assets relevant to M\&A and specific projects. An emerging quantitative approach uses option pricing theory to value patents." (p. 26).

12 Some factors are defined as 'stoppers', i.e. those that would lead to stop the patenting, commercialisation or internationalisation process. For example: the invention is not sufficiently inventive or novel; the expected revenues from commercialization do not cover the costs of protection, etc.
} 
Indeed, as regards the timing of the decisions to be taken by TTOs, Fernández-Sánchez and Muñoz-Orellana (2016) note that "a single research result may imply keeping a file open for more than twenty years, although the most intensive part of the work tends to be concentrated in the first three years. Each of the tasks carried out and milestones reached consume a variable amount of resources, depending on the context (geographic and temporal), the nature of the patent and its transfer to a third party" (p.3). Furthermore, "the decision about internationalisation must be taken around ten months after filing (end of the priority year and possible PCT filing), and eventually, 26-28 months from filing (entry in the PCT national phase)" (p.13).

As we will describe later, the usual practice in the Andalusian universities reviewed, and other public institutions interviewed more informally, is to only enter the PCT national phase if there is a technological cooperation in place or a licensing agreement signed and partners or licensees can cover the cost and take control of the internationalisation process from then onwards. In a context of uncertainty and limited budget allocated to patenting costs, TTOs would abide by the rule and will be strict in the screening process to select the patents that can be filed internationally. However, there may be exceptions, errors of judgement or unexpected failures in licensing negotiations after the international extension has taken place. A very supportive policy environment to patenting and commercialisation of university inventions, where universities often enjoy fee discounts, subsidies, etc., may also relax screening conditions for internationalisation.

The literature on the determinants of patent internationalisation at universities and public research organisations is scarce. One notable example is Romero de Pablos and Azagra-Caro (2009), who show that patent internationalisation at the Spanish National Research Council (CSIC), the largest public research organization with more than 120 institutes in all disciplines and in different regions in Spain, has been strongly influenced by the political and normative context and reinforced by technological cooperation. They take an interdisciplinary approach, and study the factors that determined patent internationalisation at CSIC over the years, from both a historical and an economic perspective. Historically, they examine trends in patent applications filed between 1939 and 2005, in terms of technology fields and collaboration patterns, and how they are influenced by political and normative changes in Spain. They conclude 
that international patenting at CSIC has gone in parallel to increased technological cooperation and clearer institutional and legal frameworks. For the economic analysis, they focus on the more recent and open years, 1987-2005 and also find that technological cooperation is an important determinant of patent internationalisation at CSIC. This is also the period when Spain signed the European Patent Agreement (EPA), in 1986, and the PCT, in 1989. As a consequence, they note that "after the EPA and the PCT came into force direct foreign applications are rare as compared with international extensions" (p.335).

There are many similarities in the way Spanish public universities and public research organisations deal with patenting and technology transfer, since both types of institutions are affected by the same general legal framework and economic context, and technology transfer is essential for both as non-practicing entities. However, public universities deserve an independent study. First because their large degree of autonomy implies that internal rules and practices may largely differ from one university to another (García-Aracil et al 2016). Second, because they depend on their regional governments, whereas large public research organisations (as CSIC) depend on the central government. Third, because public universities have benefited for many years from privileges that CSIC and other public research organisations have not had access to, such as the exemption from patenting fees in Spain.

Cartaxo and Mira Godinho (2017) study the determinants of the performance of university TTOs in Portugal in 2006-2008 from the institutional and resource-based theoretical perspectives and conclude that outcomes are influenced both by the diverse nature of the TTOs and the resources they employ. More precisely, according to the institutional point of view, the lack of patenting commitment and motivation of academics is an important obstacle to technology transfer; and in consonance with resource-based view, TTO's work is strongly affected by resource constraints and different efficiency levels, where older TTOs tend to be more efficient due to the steep learning curve of human resources. However, these are dynamic processes, and as such the relative importance of institutional factors and resources may be different at different stages. Following the study of Markman et al. (2005) on innovation speed, they note that institutional incentives and faculty behaviours may matter more at the 
early stages (discovery and disclosure) whereas TTO budgetary and administrative restrictions may be more important at later stages (patenting and commercialisation).

In what follows, we first provide some information about the legal and institutional context that affects university patenting in Spain to then examine the link between patent internationalisation and licensing. More precisely, we will perform econometric analyses to estimate the correlation between the decision to extend patent protection abroad and the existence of a licensing agreement on the patent, conditional on available information on some of the factors that may affect the TTO decision making process, such as the technological features of the invention or the experience and resources of the TTO.

\section{University patenting in Spain}

The Spanish Law 11/1986 of Patents and Utility Models has structured the Spanish patent system during the past thirty years was closely modelled on the European Patent Convention, signed by Spain also in 1986 (effective in 1987) (Martinez, 2009). One important difference between the Spanish law and the European code nevertheless was the lack of substantive examination required for granting patents at OEPM. In 2001, a Royal Decree introduced the possibility of granting national patents subject to substantive examination for those applicants who requested it and paid an additional fee. ${ }^{13}$ Nevertheless, very few applicants have chosen this alternative since then. Another change introduced in 2001, was the exemption for all Spanish public universities from paying fees at OEPM (only Spain and Portugal benefited from a 100\% patent fee exemption for universities in Europe). This exemption covered filing and renewal fees, as well as fees for substantial examination at OEPM and searching fees for PCT international filings when OEPM acted as receiving office. ${ }^{14}$ As regards the

\footnotetext{
13 Royal Decree No. 996/2001 of 10 September

${ }^{14}$ See the 2001 Organic Law of Universities Article 80.1 for the OEPM fee exemption for universities. Other public research organisations, such as CSIC (which is the largest patent applicant at OEPM), still had to pay all patenting fees related to the acquisition, enforcement, transmission and renewal of rights for patents and utility models at the OEPM. Furthermore, this exemption does not apply when the public university co-owns the patent with private companies or other research public organizations. In that case each institution has to pay the share of the fee corresponding to the percentage of ownership previously determined. For an international comparison refer to WIPO (2014) "Fee reductions for small and medium sized enterprises ("SMEs"), universities and not for profit research institutes", available at http://www.wipo.int/meetings/en/doc_details.jsp?doc_id=272010 . According to the new Spanish Patent Law that entered into force in April 2017, Spanish public universities can apply for 50\% reimbursement
} 
international extension of patent protection, Spain had signed the most important international treaties by the late 1980s, including the PCT in 1989. See Annex 2 for a detailed description of the PCT route.

Although patenting activity and knowledge transfer are usually considered of secondary importance in the assessment and evaluation of research performance at PROs in Spain, where the priority is to have high quality scientific publications, patents have been gaining more importance gradually in the curriculum of researchers (Guasch, 2007). The National Evaluation Commission of Research Activity (CNAI) was created in 1989 in order to evaluate at the national level the scientific productivity of Spanish academic researchers and reward high quality contributions developed in the past (with evaluations being possible every six years). Although these contributions were initially restricted to scientific publications, a new field called 'technology transfer and innovation' was added in 2010. This field considered patents and other forms of protection of industrial or intellectual property in exploitation (demonstrated by a change of ownership or licensing agreement). CNAI rules explicitly mentions in the criteria that a higher weight will be given to patents granted by the Spanish Patent Office via substantive examination and that "the international extension of the patent (national, European, international) will be taken into account, with more value given to broader scope of the protection" and adds that "patent applications filed in the period of reference that are not yet being used will also be taken into account although considered of secondary importance. ${ }^{15}$ Thus, the national evaluation system of scientific and technological production puts the emphasis on exploitation (transfer or license) and international extension (the higher the geographical scope, the better) at the time of valuing the patents invented by Spanish researchers. Furthermore, patent commercialization incentives for university professors, such as shares in royalties from patent licensing, have also been introduced in most Spanish universities in recent years.

of all filing and renewal fees at OEPM (65\% if the filing is done electronically), which implies that they do not have a full fee exemption any more. Nonetheless, the new law also states that they could ask for $100 \%$ reimbursement of the fees provided they can certify that the patent is being exploited as stipulated in Article 90, which rules about the 'obligation to exploit patents' and the conditions under which compulsory licensing can be imposed. Article 90.2 says literally that "the exploitation must be done within four years from the filing date, or three years from the publication of the grant, whichever is longer".

https://www.oepm.es/export/sites/oepm/comun/documentos_relacionados/Noticias/2015/2015_07_27_Nu eva_Ley_de_Patentes_BOE-A-2015-8328.pdf

${ }^{15}$ https://www.mecd.gob.es/mecd/servicios-al-ciudadano-

mecd/catalogo/general/educacion/050920/ficha.html 
According to The Spanish Law of Patents (1986), Article 20.4., the Statutes of each Spanish university shall determine the terms and the amount of participation of the scientists in the earnings obtained by the university from exploitation or transfer of rights over inventions. ${ }^{16}$

Figure 1 below plots the number of patent applications filed by Spanish universities at OEPM between 1998 and 2012 ${ }^{17}$; distinguishing between those extended internationally using the PCT system and those amongst the latter that reached the national phase in foreign patent offices (often including EPO and USPTO). The number of total patent filings has clearly increased over the years, as well as the number of PCT filings, but the number of patents with subsequent filings reaching foreign national phases has remained more or less constant.

Figure 1. Patent applications filed by Spanish universities, 1998-2012

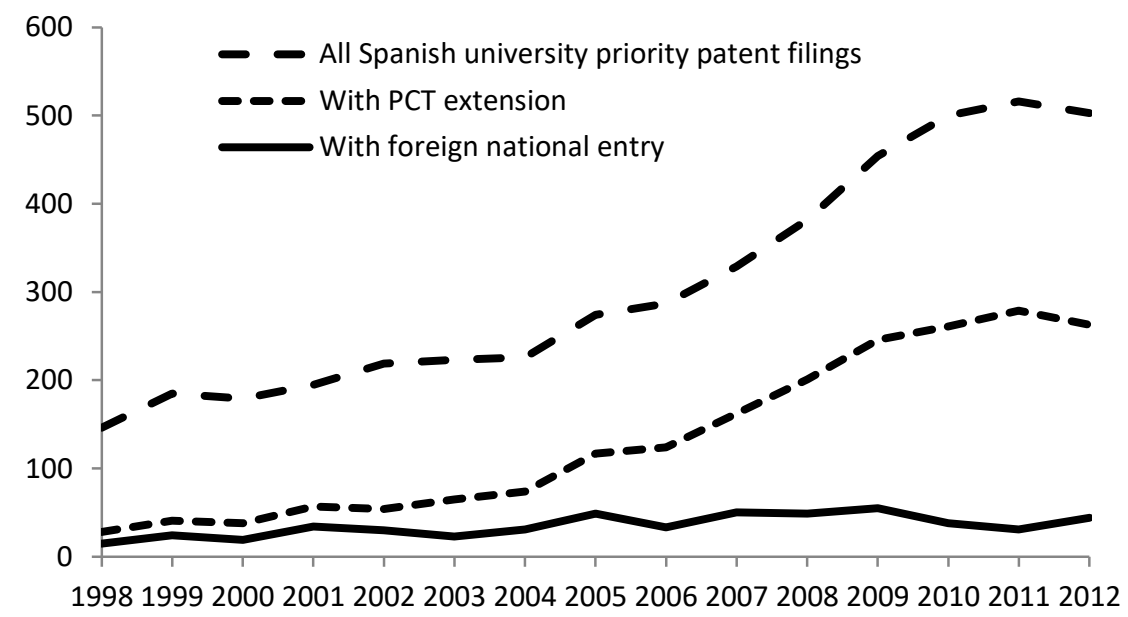

Source: Own elaboration from Patstat. University patents identified by the KUL-ECOOM Eurostat algorithm, as reported in Patstat.

\footnotetext{
${ }^{16}$ Lach and Schankerman (2008) find a positive relation between royalty incentives and the value of patents using data from US universities, which is stronger for private than for public universities in the US. However, del Barrio Castro and Garcia Quevedo (2009) find no relation between royalty shares and scientists' performance in terms of patenting at Spanish universities; institutional framework and specific characteristics of universities seem to be more important to explain differences across universities. ArqueCastells et al (2016) investigate the impact of royalty sharing on patenting or licensing income in the period 2007-2011 for 15 Portuguese and 39 Spanish universities. They use a university-level dataset, TTO and inventor's survey and conclude that royalty shares have been ineffective at improving patenting or licensing income, possibly for two reasons: low number of licensable inventions and TTOs not being sufficiently effective in commercializing inventions.

17 The sectoral allocation of applicants, to distinguish patents filed by universities from patents filed by other types of applicants relies on the methodology developed by KUL-ECOOM for Eurostat, available in the most recent versions of Patstat and described in Du Plessis et al (2009).
} 
How many of these patents are exploited by private companies? It is difficult to know. The problem lies in finding information at the patent level on technology transfer, in the form of licensing agreements, changes of ownership, creation of spin-offs using the patented technology and any other technology transfer channel relying on the patented technology. Institutions and associations tend to publish information on number of licenses or income from licensing agreements at an aggregate level, they seldom publish information connecting technology transfer agreements to specific patents.

The best source of information on knowledge transfer activities of Spanish universities would be the annual survey of the association RedOTRI, which is the network of technology transfer offices of Spanish universities (public and private) and a small number of public research organisations. However, the annual report from the survey tends to publish only aggregate counts for all reporting institutions (public and private universities, as well as public research organisations members of the association) and all kinds of IPRs altogether. ${ }^{18}$ For some years the annual survey report has also released individual responses to a number of questions for those institutions allowing so.

Table 1 below presents a statistical summary of the responses from individual public universities to questions related to the number of full time equivalent TTO personnel, revenues from $R \& D$ contracts and consulting with private firms and other entities, number of spin-offs created and revenues from IPR licensing contracts signed in 2006, 2008 and 2010. What these responses show, above all, is the large heterogeneity that characterizes technology transfer capacity and activities across different public universities in Spain, with the number of TTO personnel (full time equivalent) ranging from 1 to 31 in 2008, and about three spin-offs created every the year per institution on average, with a maximum of more than 10 in some universities. Licensing revenues from all kinds of IPRs (including patents, but also software, copyright, materials, etc) are modest, in the range of 60-70.000 Euros per year on average and the median growing substantially in the period from 8.000 in 2006 to 30.000 in 2010 . Finally, the table also shows that $\mathrm{R} \& \mathrm{D}$ contracts and consulting, which is a very broad category

\footnotetext{
18 Between 2007 and 2010 the RedOTRI annual survey also published graphs breaking down aggregate counts by type of IPR, reporting that the responding member institutions had signed 94, 92, 112 and 122 patent licensing agreements in the years 2007, 2008, 2009 and 2010. In 2007 the number of institutions responding to the question about revenues from licensing were 52 and in 200855 , out of a total of 59 members, of which 48 are public universities.
} 
covering contracts in all research areas (not only technology related ones), are a much more important source of revenues from public universities in Spain than licensing contracts, with more than 8 Million Euros perceived per year on average.

Table 1. Responses from Spanish public universities to RedOTRI annual survey

\begin{tabular}{|c|c|c|c|c|c|c|c|}
\hline \multicolumn{4}{|c|}{ TTO Staff (full time equivalent, FTE) } & \multicolumn{4}{|c|}{ R\&D contracts and consulting (Thousand Euros) } \\
\hline & 2006 & 2008 & 2010 & & 2006 & 2008 & 2010 \\
\hline Mean & 9.59 & 11.49 & 7.45 & Mean & $8,673.21$ & $12,780.13$ & $9,789.97$ \\
\hline Median & 8.00 & 9.59 & 7.50 & Median & $6,243.00$ & $9,402.00$ & $6,975.00$ \\
\hline Std. Dev. & 5.71 & 7.71 & 3.99 & Std. Dev. & $8,905.71$ & $16,579.71$ & $14,890.99$ \\
\hline Min & 3.00 & 1.00 & 1.00 & Min & 218.00 & 888.40 & 798.00 \\
\hline Max & 27.00 & 31.00 & 16.00 & Max & $37,798.00$ & $86,170.00$ & $78,718.00$ \\
\hline $\mathrm{N}$ & 29 & 39 & 39 & $\mathrm{~N}$ & 29 & 39 & 39 \\
\hline \multicolumn{4}{|c|}{ Number of spin-offs created in the year } & \multicolumn{4}{|c|}{ Licensing contracts, all kind of IPRs (Thousand Euros) } \\
\hline & 2006 & 2008 & 2010 & & 2006 & 2008 & 2010 \\
\hline Mean & 4.25 & 2.28 & 2.93 & Mean & 71.81 & 69.11 & 59.27 \\
\hline Median & 3.00 & 1.00 & 1.50 & Median & 8.00 & 9.63 & 30.00 \\
\hline Std. Dev. & 5.49 & 3.33 & 3.55 & Std. Dev. & 156.81 & 125.95 & 84.63 \\
\hline Min & 0 & 0 & 0 & Min & 0 & 0 & 0 \\
\hline Max & 22 & 12 & 13 & Max & 742.00 & 653.00 & 340.00 \\
\hline $\mathrm{N}$ & 29 & 39 & 39 & $\mathrm{~N}$ & 29 & 39 & 39 \\
\hline
\end{tabular}

An alternative source of information on technology transfer at the patent level could be the data on legal events such as licenses and changes of ownership registered at the patent offices where the patent seeks protection. ${ }^{19}$ Even though registration is non exhaustive, the propensity to register tends to be higher for changes of ownership than for licenses (Ciaramella et al 2017). We checked in the Patstat legal status database (version April 2016) to find out how many of the Spanish priority patents filed by Spanish universities had registered a contractual license or change of ownership at the OEPM but we only found a handful registered per year, which evidenced the low propensity that universities have to declare them to the OEPM. ${ }^{20}$

19 A number of economic scholars have started to use such information as evidence of the existence of
patent markets, using data from the USPTO (Serrano 2010, Graham et al 2015) and EPO (Ciaramella et al
2017) for the EPO) as well as from national registers of European countries such as France (Meniere et al
2012 ), Germany (Gaessler 2016) and Spain (Penasco et al 2016).
20 Moreover, the Patstat legal status database does not include the name of the licensee (only the date
where the licensing agreement is published in the OEPM official gazette) and as regards changes of
ownership, where the name of the new owner is published, the difficulty is to distinguish between simple
changes of names, transfers from the university to the inventors (if the university is not interested in the
patent anymore) or transfers of shares among the initial owners, and real changes of ownership derived 
In view of the scarcity and limitations of available information at the patent level on licensing agreements and the use of patents for technology transfer at universities, in what follows we will focus on the region of Andalusia and take advantage of the fact that the annual reports of the regional $R \& D$ activities published information between 2003 and 2009 on all the licensing agreements signed by the public universities of the region and the specific patent applications involved in those agreements.

\section{Case study: Andalusia}

Andalusia is the second largest Spanish autonomous community. It was until 2013 one of the Southern European regions classified by the European Commission as lessfavoured (Coronado et al, 2008), because its GDP per capita was less than $75 \%$ of the EU average. ${ }^{21}$ The region has nine public universities ${ }^{22}$ and a long tradition in managing the regional university system autonomously. The regional government of Andalusia was one of the first to benefit from the Spanish decentralisation process that started in the early 1980s, and has full competence in education policy since 1982. Andalusia is also the second Spanish region in terms of university patents (Coronado et al, 2004; Acosta et al 2005).

\subsection{Interviews}

We carried out nine semi-structured interviews to personnel of the TTOs from the nine universities of Andalusia with the aim to better understand the internationalisation decision making process and relevant contextual information about the technology transfer process and resources at the different universities sampled. Interviewees were all asked about: 1) year of establishment of TTO, personnel and university invention regulations; 2) patent royalty distribution rules in place and changes over time; 3) patent

from patent acquisitions by private firms that would reflect technology transfer activity.

21 In 2004 and 2007, when newer member states entered the European Union, the average GDP was reduced and Andalusia changed its status from Objective 1 region to Transition region. This implies that is GDP per capita is between 75 and 90 percent of EU average.

22 We do not consider the International University of Andalusia and the Menendez Pelayo International University because they offer only postgraduate and specialty courses and do not belong to the university TTO network. 
internationalisation practices, rules and exceptions; 4) availability of subsidies for patent internationalisation. The interviews were done by phone and email between the months of September and October 2014. The persons interviewed were in charge of IPR management at the TTOs. They responded to the questions and directed us to the relevant documents and university regulations. Interviewees were also asked about patent licensing agreements signed and spin-offs created per year, however such information was considered confidential and more difficult to obtain from interviews, which led us to rely mainly on information which had already been made publicly available. Information on licensing agreements and spin-offs created was then obtained from the Annual Reports of the Andalusian Plan for Research, Development and Innovation (2003-2009), hereafter referred as the annual PAI reports. Licensing agreements were easily linked to specific patents because the patent number of the patent licensed was published in the reports. However, we could not link spin-offs to patents because information about the promoter team of the spin-off (which would have been useful to link inventors and spin-offs) was only available for one year (2003). ${ }^{23}$

The interviews and documents reviewed showed that most universities had established their TTOs at the end of the 1980s or mid-1990s. The youngest one is the University Pablo de Olavide established in 2000 (see Table 2 below).

Information about TTO personnel and evolution over time was considered confidential or difficult to obtain. In any case, information reported occasionally per institution for some years in the annual report of the Red OTRI Universidades indicates that the TTOs of the public universities from Andalusia had employed on average 6-10 technicians between 2003 and 2009. ${ }^{24}$

\footnotetext{
${ }^{23}$ A few universities publish some individual information since 2006 in the annual survey report of the national network of TTOs (Red OTRI Universidades, http://www.redotriuniversidades.net), such as the number of full time equivalent (FTE) technicians working at the TTOs and spin-offs created in the year, but the number of patent licensing agreements is not published in the report, neither at the individual level, nor at the aggregate level for all Spanish universities TTOs. What is published at the aggregate level is the total number of licensing agreements signed in the year, which comprises licensing of patents, software, databases, know-how and biological materials. At the individual level universities only publish total revenues from licensing agreements obtained during the year, without mentioning the number of agreements, their breakdown by type of subject matter or the year of signature of the agreement.

${ }^{24}$ Some information on the number of TTO technicians has been published in the annual survey reports of the Spanish Red OTRI on a voluntary basis since 2006, however, of the nine universities from Andalusia, only seven have published some figures at least one year between 2006 and 2009, but not on a regular basis. The University of Almeria reports 6 TTO technicians (full time equivalent, FTE) in 2006, 7 in 2007 and 7 in 2008, but the report of the Red OTRI annual survey report does not provide individual data for University of Almeria in 2009. University of Granada reports 8 technicians in the annual report of 2006, 9
} 
The interviews also confirmed that the majority of public universities from Andalusia have internal regulations in place regarding the protection of invention or distribution of royalties from licensing contracts, most of them since the 2000s, or earlier. The Universities of Seville and Granada, which have regulations since 1995 and 1998 respectively, only a few years after their TTOs were created.

With regard to the distribution of royalty shares, University of Cadiz has the highest percentage attributed to inventors (90\%) following an increase in 2007 (from the 50\% established in 2000). University of Granada and Jaen shares $60 \%$ of the royalties with inventors, all the others give inventors $50 \%$ of the royalties obtained from licensing their inventions.

As regards the international extensions of patents, according to the internal normative and the interviews performed, the universities of Cordoba, Granada, Jaen and Seville seem to have the most restrictive rules, as they explicitly require having a licensing agreement signed for the patent for it to proceed with international extension, although they also allow for exceptions, but in general all universities place a strong weight on market interest in the patent and commercialisation potential in order to extend its protection to foreign countries. More precisely:

- There is no internal regulation providing guidance on internationalisation of patents at the University of Almeria. A university Research Committee ${ }^{25}$ decides on a caseby-case basis after examining whether the patent has possibilities to be introduced in the market and if it is positive, they will proceed to the international extension of the patent.

- At the University of Cadiz, for PCT extensions there must be a favourable commercialisation report (although not binding). This report is made in accordance with the existing evidence and proof of market interest, and according to the score of a method of evaluation of its commercial potential. Ultimately, it is at the

in 2007 and 11 in 2008, but there is no information in the 2009 report. The same happened for University of Jaen, which only published figures for 2006 (4 technicians, FTE), University of Malaga, which only reported 9 technicians in 2007 and in 2008, the University Pablo Olavide with 9, 4 and 5 for 2006, 2007 and 2008, respectively, University of Seville with 9 technicians in 2009,

25 The University Research Committee is composed by the Rector, the Vice President for Research, Development and Innovation, the Directors of Secretariat, four teaching and research staff, one student and one staff from administration and services (http://cms.ual.es/UAL/universidad/otrosorganos/comisioninvestigacion/index.htm). 
university Commission of Patents ${ }^{26}$ where it is decided whether or not to extend the patent. In case of exclusive licenses, it is the licensee who bears the cost of the internationalisation.

- At the University of Cordoba, internal rules establish that international patent extensions will only take place when there is a commercial interest in the patent, and proof of the existence of a licensee can be provided.

- The normative regarding inventions at the University of Granada requires having a licensing agreement signed in the first eleven months from the priority date in order to extend national patents abroad. The licensee will then have to take charge of the processing fees and assume a formal commitment to cover the costs of maintenance. Beyond the eleven months, if there is no licensing agreement envisaged, the university will consider that researchers are not interested in the international extension. However, there can be exceptions to the rule, for instance if the TTO has financial resources or if the patent is judged to be of high value. In those cases, they will proceed to the extent of it, considering that this short period may not be enough to find a licensee and more time is needed. ${ }^{27}$

- In the case of the University of Huelva, international patent extension is not regulated by internal regulations, but according to the TTO technician interviewed researchers can decide to extend the patent if they foresee commercialisation possibilities.

- In conformity with the normative of the University of Jaen, in the first twelve months from the priority date, the TTO, either at its own initiative or following the inventor's interest, may apply for the international extension of the patent. In general, they will only proceed to the international extension of a patent when there

\footnotetext{
26 The Patent Commission of the University of Cadiz is composed of the Rector, as president, the ViceRector of Research, Technological Development and Innovation, the Director of the OTRI, the technical responsible for the Industrial Property area and another technician of the OTRI who will act as secretary, as well as two University of Cadiz researchers with experience in patent application and exploitation (one of them in training). In case it is considered necessary, the Commission may invite other members, whose knowledge and expertise may be relevant for the decision, both from the University Community and outside the University.

${ }^{27}$ Article 13 of the internal IPR management rules approved at the University of Granada in January 2017 sets out explicit criteria for internationalization and maintenance of IPRs confirming that there must be a licensing agreement with a third party to extend the patent internationally, and this decision has to be taken one month before the priority year ends, unless the university has an interest in the internationalisation of the patent for university policy or strategic reasons in which case it could be extended without the need of having a licensing agreement. This article also conditions the maintenance of the patent to budgetary constraints and reports about its commercialisation. More information (in Spanish) available here: http://otri.ugr.es/patent-blog/aprobada-la-nueva-normativa-sobre-propiedadindustrial-e-intelectual/ (accessed July 2017).
} 
is a company interested in commercial exploitation and it signed the appropriate license agreement for that purpose. The licensee would have to cover the costs arising from the international extension of the patent. Exceptionally, if the research group has resources to do, it may apply for the international extension of the patent without necessarily having found a licensee yet.

- Regulations at the University of Malaga have no explicit requirements for international patent extension, however, the internal rules of the TTO consider patent valorisation estimations and indications before taking the decision to extend patent protection abroad.

- At the University Pablo Olavide, it is the Vice Rector for Research and New Technologies, based on report previously issued by the $\mathrm{TTO}^{28}$, who decides in agreement with the inventors about the international extension of the patent in the first twelve months from the priority date of filing at the OEPM. It is then being understood that if such a decision is not taken, the scope of protection will definitely be limited to the national territory.

- Finally, at the University of Seville, international patent extensions occur when there is a licensee or a company expression of interest, with the approval of the TTO, although there is also always the possibility of the researcher covering the costs of application and maintenance of the extension.

Finally, information from interviews and TTO webpages indicated that some universities give intramural grants for internationalisation of patents filed by the university (University of Seville, University of Jaen and University of Almeria) provided the inventors can offer sufficient proof of commercialisation potential and value of the invention. ${ }^{29}$ We interpret the latter as an indication of the existence of more stringent rules for internationalisation at the institutional level, in a context of increasing uncertainty and budget constraints, as these calls effectively made different university

\footnotetext{
${ }^{28}$ The TTO have to issue a report recommending or not the internationalization of the patent, taking into account different factors such as: i) the state of the patent application (search report, etc), ii) the strategy of the university (the institution may want to support a specific technology area), iii) whether private firms have expressed interest to commercialise it; iv) the quality of the patent; and v) whether it can generate further patenting.

${ }^{29}$ OEPM
} 
inventors compete with each other to proof the merits and commercial potential of their inventions. ${ }^{30}$ Table 2 below summarises the most relevant information just described.

Table 2. Andalusian universities

\begin{tabular}{|c|c|c|c|c|c|c|c|c|c|c|}
\hline \multirow[b]{2}{*}{ University } & \multirow{2}{*}{$\begin{array}{c}\text { Creation } \\
\text { of the } \\
\text { TTO }\end{array}$} & \multirow{2}{*}{$\begin{array}{c}\text { Internal } \\
\text { Regulation } \\
\text { on } \\
\text { inventions }\end{array}$} & \multicolumn{5}{|c|}{ Royalty distribution } & \multicolumn{3}{|c|}{ International patent extension } \\
\hline & & & Inventors & Dept. & $\begin{array}{l}\text { Research } \\
\text { group }\end{array}$ & University & TTO & $\begin{array}{l}\text { Rules recommend } \\
\text { evidence of } \\
\text { transfer potential } \\
\text { to allow } \\
\text { international } \\
\text { extension }\end{array}$ & $\begin{array}{c}\text { Rules explicitly } \\
\text { require having } \\
\text { signed a } \\
\text { licensing } \\
\text { contract for } \\
\text { international } \\
\text { extension }\end{array}$ & $\begin{array}{l}\text { Intramural } \\
\text { grants for } \\
\text { international } \\
\text { extension }\end{array}$ \\
\hline Almeria $^{(\mathrm{i})}$ & 1993 & 2008 & 50 & & 20 & 10 & 20 & Yes & No & Yes \\
\hline \multirow[t]{2}{*}{ Cadiz } & \multirow[t]{2}{*}{1988} & 2000 & 50 & 25 & & 25 & & \multirow{2}{*}{ Yes } & \multirow{2}{*}{ No } & \multirow{2}{*}{ No } \\
\hline & & 2007 & 90 & & & 10 & & & & \\
\hline \multirow[t]{2}{*}{ Cordoba } & \multirow[t]{2}{*}{1989} & 1993 & 50 & 25 & & 25 & & \multirow{2}{*}{ Yes } & \multirow{2}{*}{ Yes } & \multirow{2}{*}{ No } \\
\hline & & 2008 & 50 & & 25 & 25 & & & & \\
\hline Granada & 1989 & 1998 & 60 & 15 & & 25 & & Yes & Yes & No \\
\hline Huelva & 1994 & 2002 & 50 & 25 & & 25 & & Yes & No & No \\
\hline \multirow[t]{2}{*}{ Jaen } & \multirow[t]{2}{*}{1993} & 2000 & 60 & 10 & & 30 & & \multirow{2}{*}{ Yes } & \multirow{2}{*}{ Yes } & \multirow{2}{*}{ Yes } \\
\hline & & 2009 & 60 & 20 & & 20 & & & & \\
\hline Malaga & 1989 & 2006 & 50 & 25 & & 25 & & Yes & No & No \\
\hline Pablo Olavide & 2000 & 2007 & 50 & 25 & & 25 & & Yes & No & No \\
\hline Seville & 1989 & 1995 & 50 & 25 & & 25 & & Yes & Yes & Yes \\
\hline
\end{tabular}

Note: (i) The university of Almeria has no specific norm or internal regulation, 2008 is the year of the agreement of the Governing Council of the University of Almeria (28/11/2008) specifying the distribution of royalty shares.

Source: Own elaboration based interviews, university websites, the normative of each university for internal regulations and intramural subsidies.

\subsection{Data}

For the last part of our study, a statistical analysis at the patent level to test if patent licensing is significantly correlated or not with the decision to internationalise the patent, conditional on relevant patent and institutional characteristics, we gathered data on 631 patent families filed by the nine public universities from Andalusia with priority years between 1998 and 2009 (465 of them filed in 2003-2009, of which 21 were cofiled with private firms, thus 444 filed solely by public universities in 2003-2009). ${ }^{31} \mathrm{We}$ stop at 2009 to allow sufficient time for international extensions to be recorded in patent databases and for patents to receive citations, a widely used indicator of technological

\footnotetext{
${ }^{30}$ See for example call from the University of Seville to support PCT filing and PCT national phase entry costs : http://investigacion.us.es/convocatorias/ver/803.

${ }^{31}$ There are more Spanish patents in our sample (668) than patent families (631) because some patent families include more than one national filing at OEPM.
} 
importance. 2009 is also the last year for which the annual PAI reports included patent numbers linked to licensing agreements.

We first compiled the list of all patents filed nationally by universities in Andalusia from the database called INVENES available at the website of the $\mathrm{OEPM}^{32}$ and then added information at the patent level from the OEPM, the EPO Worldwide Patent Statistics database (Patstat) and other secondary sources. We harmonized the fields when necessary to build our variables, such as applicant names and types (e.g. university or private firm).In terms of collaboration, $16 \%$ of patent families filed by Andalusian universities are filed jointly with other applicants, most of them public sector institutions. A major partner is the Spanish National Research Council (which operates ten research centres jointly with universities in Andalusia), followed by other Spanish universities. Patents co-filed with private firms only represent $5 \%$ of the total.

Information on technology transfer at the patent level was obtained from the annual PAI reports, where patent level data on licensing agreements signed at public universities in Andalusia was published between 2003 and 2009, as mentioned earlier. ${ }^{33}$

Information on international patent protection was obtained from Patstat (April 2014), where we can observe if a Spanish priority filing is extended internationally via the PCT in the first 12 months from filing and whether there are subsequent foreign filings after the PCT international phase, that is, if the internationalization process reaches the national phase (or in the case of EPO, the so-called regional phase, within 30 months from the priority filing provided the patent took the PCT path). In addition to determining how far in the internationalization process the university decided to go with

\footnotetext{
32 The Spanish filings included in the EPO Worldwide Patent Statistics Database (Patstat) lacks information on applicant addresses, thus preventing us from fully identifying university patents filed from the region of Andalusia if the applicant name was incomplete. For the INVENES expert search, we used the keyword "university" and introduced the codes of the Andalusian provinces in the corresponding fields, but that only gave us patents having first applicant with an address in Andalusia. We then did additional (more general) searches to complete our database and add other patent applications filed at OEPM in our period of interest having Andalusian universities as co-applicants, but not in the first position. We also compared our results with lists provided by OEPM, and after some iterations and additions, we completed our database, which we believe includes all OEPM filings filed by universities between 1998 and 2009.

${ }^{33}$ When there was a mention of a licensing agreement signed those years but the patent number was not reported, we contacted the TTO to ask them for the number. Additionally, a TTO provided us with information about licenses signed one of the years analysed that had not been included in the annual PAI reports. We therefore are quite confident about the completeness of the licensing information we rely on. We should note that when the licensing agreement is non-exclusive, the same patent can be subject to more than one licensing agreement, but we simply consider for the analysis whether a patent is licensed or not, regardless of the number of licensing agreements it might have been the object of.
} 
each patent (national, international phase at PCT or PCT national entry), we also classified families according to their geographical scope, and defined the size of the family as the number of different patent authorities where the family members had been filed.

The map below (Figure 2) provides a general view of the geographical scope of the 67 families with priority years 1998-2009 that entered the national phases of the PCT process. These families are those for which applicants sought protection in specific jurisdictions 30 months after priority. ${ }^{34} \mathrm{EPO}$ receives the largest number of filings (65 PCT families have filings at EPO), which is not surprising as it is the entry point to almost 40 European countries. ${ }^{35}$ It is followed by United States, 49 families, Japan with 18 and Canada with 12 . The rest of countries receive 1 to 6 families only.

\section{Figure 2. Geographical scope of international patent families filed by universities from Andalusia, priority years 1998-2009}

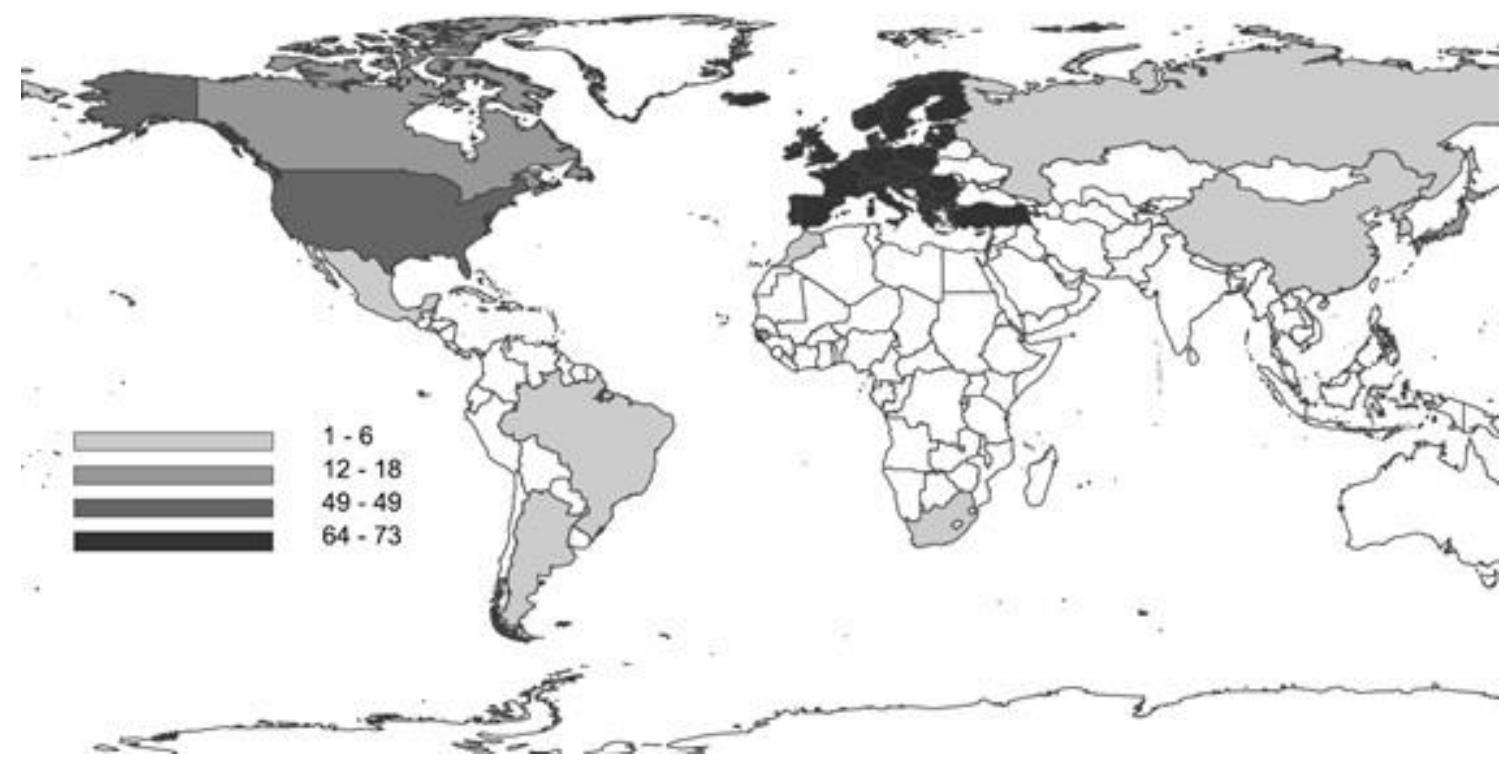

Note: PCT national entries to Australia (25) have been excluded because for many years the Australian Patent Office published international PCT filings, regardless of whether they entered the country later or not. This has been recently corrected, but the period analysed here is affected.

Source: Own elaboration based on Patstat.

\footnotetext{
34 The PCT international phase gives applicants 30 months to decide whether it is worth investing further in the international extension of the patent or not, and where to do it.

35 The member states of the European Patent Organisation (EPO) are 38 countries in October 2015. Available at https://www.epo.org/about-us/organisation/member-states.html
} 
As regards the distribution across universities, those in Seville, Granada and Malaga concentrate two thirds of all the families filed by the nine public universities in Andalusia. Adding the families filed by University of Cadiz and University of Cordoba the top five have $86 \%$ of all the families. These five universities are also the largest ones in terms of number of professors, as shown in Table 3 below. University Pablo Olavide, the youngest and smallest of all, has the highest share of internationally extended families (entering PCT national phases).

Table 3. Patent families by university, priority years 1998-2009

\begin{tabular}{lcccc}
\hline & $\begin{array}{c}\text { Number of } \\
\text { professors } \\
\text { in } \mathbf{2 0 0 3}\end{array}$ & $\begin{array}{c}\text { All patent } \\
\text { Families } \\
\text { (N=631) }\end{array}$ & $\begin{array}{c}\text { With PCT } \\
\text { international } \\
\text { extension }\end{array}$ & $\begin{array}{c}\text { With PCT } \\
\text { national } \\
\text { entries }\end{array}$ \\
\hline University of Almeria & 412 & 46 & $33 \%$ & $4 \%$ \\
\hline University of Cadiz & 820 & 73 & $70 \%$ & $12 \%$ \\
\hline University of Cordoba & 803 & 53 & $36 \%$ & $6 \%$ \\
\hline University of Granada & 2114 & 133 & $47 \%$ & $13 \%$ \\
\hline University of Huelva & 335 & 32 & $59 \%$ & $0 \%$ \\
\hline University of Jaen & 468 & 33 & $48 \%$ & $0 \%$ \\
\hline University of Malaga & 1244 & 104 & $36 \%$ & $9 \%$ \\
\hline University Pablo Olavide & 106 & 13 & $62 \%$ & $23 \%$ \\
\hline University of Sevilla & 2211 & 181 & $67 \%$ & $15 \%$ \\
\hline & Share of all patent families & $\mathbf{5 2 \%}$ & $\mathbf{1 1 \%}$ \\
\hline
\end{tabular}

Source: Own elaboration based on Patstat. The number of professors comes from www.iune.es

The increasing trend in the number of international patent families filed by public universities from Andalusia between 1998 and 2009 is shown in Figure 3 below. Of the 631 patent families filed in the period, 303 remained national and 328 started international extensions procedures via PCT, thus slightly less than half remained national. In most cases the internationalization process did not reach the PCT national 
phase entry. Of the 328 families with PCT international filings, only 67 (20\%) followed the PCT process with regional (at EPO) or national entries (in different countries).

The figure also displays the number of patent families licensed (as reported in the 20032009 annual PAI reports), 68out of a total of 465 with priority years between 2003 and $2009(15 \%)$. 
Figure 3. Patent families with Spanish priorities filed by universities from Andalusia, 1998-2009

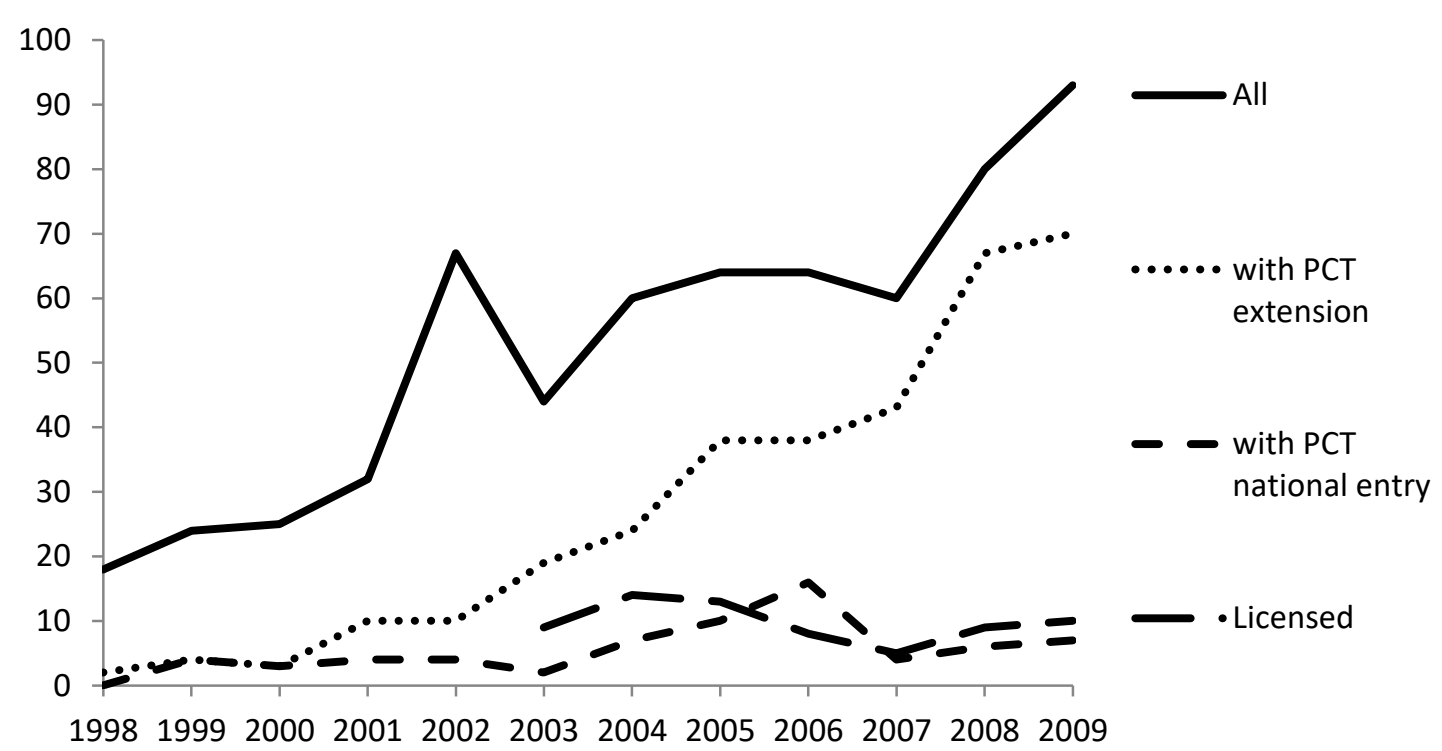

Source: Own elaboration based on information from Patstat and annual PAI reports. The last years may be affected by truncation in the patent database, due to delays in reporting of foreign national entries.

Limiting our attention to the 465 families with priority in 2003-2009, we find that they have members filed on average in 1.34 different patent offices (with a maximum of 14 , including OEPM), 36\% have remained national (only filed at OEPM), 64\% have taken the PCT route and $11 \%$ have reached the PCT national phase in different offices, for instance $10 \%$ at EPO, $9 \%$ at EPO and UPSTO and 3\% are triadic, that is have filings at EPO, USPTO and JPO. Almost all of their Spanish priority filings have been granted by OEPM (99\%), but only $20 \%$ on average have opted for OEPM substantial examination, a share that has increased over the years, from $2 \%$ in 2003 to $26 \%$ in 2009 , and only 5\% have been filed jointly with private companies. As regards their technological importance, proxied by the number of citations received from other patents, the sampled families received on average 0.36 citations in the first five years from priority, with a standard deviation of 0.97 , and $80 \%$ of them did not receive any citation in those first five years. When considering all citations received as available in Patstat April 2014 (i.e. citations received by early 2014), the share of families with no citations goes down to $74 \%$ and the average number of citations received increases to 
0.63 , although the standard deviation is even higher, equal to 1.67 , which confirms the well-known highly skewed distribution of technological importance and patent value more broadly. In terms of their broad technological distribution, 57\% are on chemicals, $30 \%$ on instruments, $15 \%$ on electrical engineering, $10 \%$ on mechanical engineering and $8 \%$ on other fields. See Annex Table A1 and Annex Table A2 for descriptive statistics and correlations between the variables used in the econometric analysis, which also include institutional characteristics of the universities filing the patents, such as their size (proxied by the number of professors), the number of patent families filed the year before the priority year of the focal patent family (as an indication of patenting experience and size), the royalty share assigned to the inventor and her research group at the university and the age of the university TTO (from the interviews, Table 2 earlier). The highest positive correlations are observed between family size and PCT entry into national phases, unsurprisingly, and between some university characteristics such as size, patenting experience and age of the TTO. There is also a strong correlation, although of a negative sign, between royalty share given to inventors and their research group and the two proxies of university size (number of professors and patent families filed the previous year).

\subsection{Empirical analysis}

For the econometric analysis presented in this section, we focus on the 465 patent families with priority years 2003-2009 and exclude those amongst them that were cofiled with private firms (21), which leaves us with a sample of 444 families. ${ }^{36}$

We carry out three different econometric analyses where the unit of observation is the patent family and variables are consolidated at the family level (e.g. citations, technology fields, PCT, applicants, etc). Our objective is to show to what extent having a licensing agreement is correlated with international patent protection, conditional on information available on several patent characteristics and institutional features that have been identified in the literature as relevant for the decision making process at TTOs.

\footnotetext{
36 We exclude patent families with private co-applicants from the analysis in order to keep a homogeneous subsample to estimate the link between internationalisation and technology transfer in the form of licensing. Co-ownership with industry is another form of technology transfer, and would likely reflect the existence of a previous $R \& D$ contract.
} 
Table 4 sets out the results from the three econometric regressions performed. ${ }^{37}$ The first regression is a probit where the dependent binary variable is equal to 1 if there is a PCT national entry. ${ }^{38}$ The second one is a linear regression where the size of the patent family is the dependent variable. A patent family equal to one indicates that there have been no filings beyond the initial priority filing at the OEPM or the international phase of the PCT filing given that OEPM is an international receiving office. A patent family with two members would reflect that there has been a subsequent filing to the EPO, which is the main destination of subsequent filings for Spanish applicants, and even the priority office for some applicants (mainly business ones). A family size larger than two already reflects that the internationalisation process is serious and probably very costly. Finally, the third regression is an ordered logit where the dependent variable takes value 1 if the patent has remained national, value 2 if it has reached the PCT international phase and 3 if it has entered the PCT national phase in foreign patent offices. This last regression aims to estimate the relation between licensing and different degrees of patent protection, conditional on patent value indicators.

The main variables of interest in all three regressions are: i) 'licensing agreement', which takes value one if a licensing agreement was reported in the annual PAI reports 2003-2009 for the priority patent of the family; and ii) 'technological importance', which is the sum of all citations received by the family members from other patents by early 2014, the date of extraction of the data for Patstat April 2014. We also include in some of the regressions two time-varying controls for institutional heterogeneity and

\footnotetext{
${ }^{37}$ In alternative regressions (not reported) we also included substantive examination at the OEPM as an additional covariate in the regressions but its coefficient was in general not significant. In addition, as shown in Table 2, substantive examination is positively correlated with entering the PCT international phase, but negatively correlated with reaching the PCT national phase (although both correlations are very low in absolute value). This is consistent with universities asking for a substantive examination for the patents they judge as having the highest potential (based on the initial search report at the Spanish Patent Office and internal valuations), which are also those they select for PCT international phase, but are not always the same that manage to be licensed and thus continue to reach the PCT national phase. For a discussion of the advantages and disadvantages of substantive examination at the Spanish Patent Office, see the report released in 2011 by the expert group "Foro de Innovación y Patentes" (in Spanish) available here:

https://www.oepm.es/export/sites/oepm/comun/documentos_relacionados/sobre oepm/Foro de Innovaci on y Patentes/FIP Informe Examen de Fondo.pdf

${ }_{38}$ An alternative strategy would be to have a selection equation to explain the process of whether to internationalise in the first stage, and then look at the factors that influence the decision to extend the PCT application to the national phase, in the second stage. However, we do not have enough time varying information to be able to identify distinctively the determinants at each step in the decision tree. We use the ordered logit regression to estimate the effect of different variables on the likelihood to move forward through the different stages in the internationalisation process via PCT.
} 
patenting experience as of the year of the priority filing: i) the number of patent families filed by the university the previous year, to proxy for experience in patent filings, ${ }^{39}$ and ii) the number of years between the creation of the TTO and the priority year of the focal patent family. In other regressions we simply include university fixed effects to control for time invariant unobserved heterogeneity. ${ }^{40}$ In addition, all regressions include dummies for priority years and technology fields. For the latter, we use information on the five broad technological fields of the WIPO correspondence between IPC classes and fields (Schmoch 2008). ${ }^{41}$

As shown in Table 4, all regressions show, consistently with our expectations, that there is a strong link between technology transfer and international extension of university patent families, all else equal, that is, conditional on a number of relevant measurable factors influencing the decision making process at the TTO, such as technological features of the invention (technological importance of the invention, technology field), experience and resources of the TTO (age of the TTO, number of patent families filed the previous year), economic context and legal framework at the time of the invention (roughly taken into account by including the priority year of the family as control), and institutional heterogeneity of the sampled universities (university fixed effects).

The technological importance of the invention has a positive and strongly significant effect on the international extension of patent protection in all regressions. The patenting experience of the university is positively correlated with moving forward the different steps in the PCT route, but the significance decreases when the age of the TTO is controlled for as they both reflect the experience of the TTO (ordered logit). The

\footnotetext{
${ }^{39}$ The maximum value is taken in case more than one of the sampled universities appears as coapplicant.

40 The number of observations is lower when using university fixed effects in the probit regression because two universities predict failure perfectly.

${ }^{41}$ Being granted at OEPM was not considered for inclusion in the regressions, as a control on patent quality, because $99 \%$ of the patent filings sampled had been granted, as seen in the descriptive statistics. We also decided not to include the number of university professors in the final regressions and used instead the number of patent families filed the previous year as an indicator of university size as well as patenting experience, given their strong correlation (see Table A2 in the Annex). Finally, we did not include the royalty share for the inventor and research group in the final regressions displayed because of their low variation across the sampled universities and over time and the strong correlation of the variable with the number of patents filed the previous year. The strong negative correlation between royalty share given to inventors and university size could be due to the greater bargaining power of larger institutions with the average academic inventor, but deserves further exploration beyond the scope of this paper and the data at hand. Not only there could be exceptions to the rule, but also the most prolific inventors would likely receive other institutional benefits and compensations in addition to the royalty share fixed by the internal regulation. For an analysis of university incentives and patenting see e.g. del Barrio-Castro and Garcia-Quevedo 2009; Garcia-Quevedo 2010; Arque-Castells et al 2016.
} 
older the TTO and the higher number of families filed the previous year, the further along the learning curve and the more resources available, consistently with Cartaxo and Mira Godinho (2017) who find that TTO outcomes depend among other things on university size, TTO experience and number of patent applications.

The conditional correlations just described can be useful for policy makers, managers, analysts and innovation policy scholars. We show that the further a university patent goes into the internationalization process, the more likely it is to see it transferred to a private company. Our analysis is not without limitations. More fine grained information at the patent family level about the TTO decision making process, the research group behind the patent and the potential licensees of the invention would be needed to disentangle the influence of the different factors. For instance, we do not enter into timing issues to ascertain whether it happens before or during the internationalization process, but based on the interviews with TTO officers we argue that the international extension continues to its last stages for patents for which the TTO can sign a licensing agreement. In turn, patent filings are more likely to remain national when universities are not able to find a licensor, and this holds for patents of lower or higher technological importance, although consistently with previous studies, we also find that the patents of lower value or technological importance are less likely to seek international protection and thus tend to have smaller families. 
Table 4. Probability of entering the national phase, having a larger patent family or passing the different phases of international protection via PCT

\begin{tabular}{|c|c|c|c|c|c|c|c|c|}
\hline \multicolumn{3}{|c|}{ Probit } & \multicolumn{3}{|c|}{ OLS } & \multicolumn{3}{|c|}{ Ordered Logit } \\
\hline \multicolumn{3}{|c|}{ National phase entry } & \multicolumn{3}{|c|}{ Family size } & \multicolumn{3}{|c|}{ PCT phases } \\
\hline \multicolumn{3}{|c|}{$\begin{array}{c}0=\text { no national phase entry } \\
1=\text { national phase entry }\end{array}$} & \multicolumn{3}{|c|}{$\begin{array}{c}\text { Number of different patent authorities in } \\
\text { the family }\end{array}$} & \multicolumn{3}{|c|}{$\begin{array}{l}\text { 1=patent remains national, no PCT; } \\
\text { 2=patent remains at the PCT international } \\
\text { phase, no national phase entry; } 3=\text { patent } \\
\text { enters PCT national phase }\end{array}$} \\
\hline (1) & $(2)$ & (3) & (4) & (5) & (6) & (7) & (8) & (9) \\
\hline $\begin{array}{l}0.142 * * \\
(0.0574)\end{array}$ & $\begin{array}{l}0.138 * * \\
(0.0549)\end{array}$ & $\begin{array}{l}0.115^{* *} \\
(0.0532)\end{array}$ & $\begin{array}{c}0.579 * * * \\
(0.216)\end{array}$ & $\begin{array}{c}0.579 * * * \\
(0.217)\end{array}$ & $\begin{array}{l}0.535^{* *} \\
(0.214)\end{array}$ & $\begin{array}{c}1.644^{* * *} \\
(0.317)\end{array}$ & $\begin{array}{c}1.645^{* * *} \\
(0.319)\end{array}$ & $\begin{array}{c}1.599 * * * \\
(0.317)\end{array}$ \\
\hline $\begin{array}{c}0.0275 * * * \\
(0.00638) \\
0.00260 \\
(0.00198)\end{array}$ & $\begin{array}{c}0.0279 * * * \\
(0.00640) \\
0.00350 \\
(0.00219) \\
-0.00486 \\
(0.00614)\end{array}$ & $\begin{array}{c}0.0344 * * * \\
(0.00698)\end{array}$ & $\begin{array}{c}0.266 * * * \\
(0.0831) \\
0.00981 \\
(0.00940)\end{array}$ & $\begin{array}{c}0.266 * * * \\
(0.0829) \\
0.00964 \\
(0.0118) \\
0.000847 \\
(0.0201)\end{array}$ & $\begin{array}{c}0.276 * * * \\
(0.0835)\end{array}$ & $\begin{array}{c}0.474 * * * \\
(0.112) \\
0.0403 * * \\
(0.0184)\end{array}$ & $\begin{array}{c}0.474 * * * \\
(0.112) \\
0.0409 * \\
(0.0212) \\
-0.00289 \\
(0.0602)\end{array}$ & $\begin{array}{c}0.502^{* * *} \\
(0.113)\end{array}$ \\
\hline $\begin{array}{l}\text { Yes } \\
\text { Yes }\end{array}$ & $\begin{array}{l}\text { Yes } \\
\text { Yes }\end{array}$ & $\begin{array}{l}\text { Yes } \\
\text { Yes } \\
\text { Yes }\end{array}$ & $\begin{array}{l}\text { Yes } \\
\text { Yes }\end{array}$ & $\begin{array}{l}\text { Yes } \\
\text { Yes }\end{array}$ & $\begin{array}{l}\text { Yes } \\
\text { Yes } \\
\text { Yes }\end{array}$ & $\begin{array}{l}\text { Yes } \\
\text { Yes }\end{array}$ & $\begin{array}{l}\text { Yes } \\
\text { Yes }\end{array}$ & $\begin{array}{l}\text { Yes } \\
\text { Yes } \\
\text { Yes }\end{array}$ \\
\hline & & & $\begin{array}{c}0.633^{* * *} \\
(0.148)\end{array}$ & $\begin{array}{c}0.624 * * \\
(0.277)\end{array}$ & $\begin{array}{c}1.007^{* * *} \\
(0.273)\end{array}$ & $\begin{array}{c}-0.420 \\
(0.336) \\
2.969 * * * \\
(0.370)\end{array}$ & $\begin{array}{c}-0.467 \\
(1.045) \\
2.923^{* * *} \\
(1.067)\end{array}$ & $\begin{array}{c}-0.979 * \\
(0.581) \\
2.580 * * * \\
(0.600)\end{array}$ \\
\hline 0.2922 & 0.2946 & 0.3437 & 0.226 & 0.226 & 0.242 & 0.1654 & 0.1654 & 0.1954 \\
\hline 444 & 444 & 389 & 444 & 444 & 444 & 444 & 444 & 444 \\
\hline
\end{tabular}

Standard errors in parentheses, ${ }^{* * *} p<0.01,{ }^{* *} p<0.05,{ }^{*} p<0.1$. Robust standard errors in parentheses.

Marginal effects for the probit, estimated coefficients for the OLS and ordered logit.

\section{Discussion and conclusions}

We have shed light on the decision making process at university technology transfer offices in order to show that the last steps in the process of international patent extension, when costs step up, tend to be only taken conditional on the existence of a licensing agreement. Based on this, we have argued that the number of international patent families filed by a university can be used as a rough indicator of technology transfer activity mediated through patents, especially in the context of tight public university budgets and national patent systems with fee reductions for universities.

In our view, the link between patent internationalisation and technology transfer at public universities has so far been underexploited by policy makers and scholars searching for new indicators of the impact of university research on innovation. This might have been caused by the predominance of studies about patent families that either focus on business-owned patents or provide interpretations from the viewpoint of firms only. These have provided evidence of the relation between patent family size and 
patent value (Putnam 1996, Martinez 2011, van Zeebroeck and van Pottelsbergue 2011). Our study goes one step further and presents statistical evidence on the relation between patent family size and commercialisation, conditional on patent value, and complements it with qualitative evidence reinforcing such relation from interviews with technology transfer managers and information from university statutes.

Pro-patenting measures have led to growing numbers in patent applications experienced by Spanish universities in the past decades. First, the creation of technology transfer offices in the late 1980s and the continuous support given by the national and regional governments. Second, the establishment of a network of TTOs (RedOTRI) where to share expertise and information. Third, the 2001 exemption for public universities from paying fees at the OEPM as well as international searching fees in PCT procedures when the OEPM is the receiving office. ${ }^{42}$ Finally, but to a much lesser extent, the availability of subsidies from OEPM to cover the cost of patenting internationally, but only a few university patents benefited from those, as it was mainly directed to individual inventors and small and medium enterprises (see Annex 2). All these conditions have led to a boom in university patenting in Spain in the past two decades, yet a small fraction of those patents have been licensed to the private sector and eventually led to the introduction of new products and processes in the market, as it tends to be the case in all countries.

Consistently with previous studies, we find that patents that enter the PCT national phase are more likely to be of higher value or technological importance (i.e. receive more citations from other patents) than those that remain national or only reach the PCT international phase but do not enter any national or regional patent office when the time comes. The novelty of our analysis is that we further show that reaching the PCT national phase is also strongly correlated, conditional on the technological importance of the patent, with patent licensing. A finding that is consistent with the recommendations included in the statutes of the universities analysed but has not yet been used by policy makers or innovation scholars.

Although our analysis is basically descriptive, relying on correlations without pretending to infer causal relations, we believe that having shed light on this link can be helpful for future policy analyses of university patenting and for the interpretation of

\footnotetext{
${ }^{42}$ Changes included in the Organic Law of Universities 6/2001. Spain is PCT receiving office since 1995.
} 
statistics using different types of patent filings from universities and other public research organisations. The strong support given to patenting and PCT international filings at universities in Spain in recent years (with the OEPM and PCT international searching fee exemption for universities, for instance) relaxed the screening process for patenting nationally and for initiating the international protection process, but a strong screening was still in place for the later stages, when costs step up, and only a few patents reach the PCT national phase.

Further research would be needed to gather more information about university licensing contracts (e.g. exclusive or non-exclusive) and to expand the sample to other Spanish universities and longer periods of time (before and after the economic crisis), to consider other forms of technology transfer in addition to patent licensing, such as research contracts. All this would help better understand the use of university foreign filings as an 'innovation indicator'. With the data at hand, we have not been able to determine whether patenting abroad facilitates finding future licensing partners or it is instead explained by the interest of the actual licensing partners who may in fact control the internationalisation process. Our data on the timing of the licensing agreement is not detailed enough to disentangle both scenarios. We leave that question for further research, provided we can obtain more information about licensing agreements, including the specific terms of the contracts and, eventually, the history of collaborations between the partners.

International comparative studies would also be necessary to test whether the link also prevails in other countries with higher entry cost in the patent system for universities, that is, countries where there are no patent office fee reductions for universities. Nevertheless, we expect to observe a relation between commercialisation and internationalisation in other countries as well because the administrative costs related to patent fees are only part of the overall cost of patenting and entering the national phase at PCT always requires a substantial amount of additional expenses, multiplied by the number of countries where protection is sought. Results from a recent survey of the European Commission about patenting costs in different countries indicate that patent costs have influence the geographical coverage of patents filed by universities, and confirm that licensing out is generally the most important motive for patenting (European Commission 2015). 
We also leave for future research the study of how the new Spanish patent law - which entered into force in April 2017 - will affect the behaviour of universities in terms of patenting, internationalisation and commercialisation of patents. The 2001 change in the law that granted a full fee exemption at OEPM to Spanish universities occurred at a time when universities had only recently started to patent, the aim of the policy was to facilitate as much as possible their entry in the patent system, to change their culture. The change in 2017 happens in a different context, when universities have already adopted the patenting culture but all their activities have been seriously affected by the budget cuts resulting from economic crisis since 2008. The aim of the new law is to raise the quality of the Spanish patent system. It not only requires all Spanish patent filings to go through substantive examination in order to be granted, but it also states that universities will only be reimbursed $50 \%$ of the fees (instead of $100 \%$ as before) or $100 \%$ if they can provide evidence of patent exploitation or commercialisation not later than four years after filing and will no longer be exempt from paying the PCT international search fee. ${ }^{43} \mathrm{We}$ will observe, in the future, whether and how these measures affect public university decision making processes for patenting, internationalisation and technology transfer across different Spanish regions and institutions.

\section{FUNDING}

Catalina Martinez acknowledges funding from the Spanish Ministry of Economy and Competitiveness (CSO2012-32844 and CSO2016-79045-C2-1-R) and regional government of Madrid (PRODECON-CM, S2015/HUM-3491). Lydia Bares acknowledges funding from University of Cadiz, Plan Propio de Investigación 2015 (MV2015-109).

\section{ACKNOWLEDGEMENTS}

43 According to the information about fees published at the end of the text of the law in July 2015, the basic fees corresponding to filing (100.38 Euros), search (684.65 Euros) and substantive examination (389.77 Euros) at the OEPM added up to 1174,8 Euros (available at https://www.boe.es/boe/dias/2015/07/25/pdfs/BOE-A-2015-8328.pdf). 
We are grateful to the Spanish Patent and Trademark Office and the Technology Transfer Offices of Andalusian Universities for their help with the data and for kindly answering our questions and requests. We would also like to thank María Dolores León Rodríguez, Alejandro Lemus Carretero, Cándido Andrés García, Rebeca Fernández Sánchez, Valerio Sterzi, Francesco Lissoni, Ernest Miguélez, Miguel Mulet, Gerardo Penas and Domingo Represa for very helpful discussions, as well as two anonymous referees for their comments and suggestions. A preliminary version was presented at the ERSA 55th Congress "World Renaissance: Changing Roles for People and Places", Lisbon, Portugal, 25-28 August 2015, we thank participants for their comments. This work was initiated during a research visit of Lydia Bares at the CSIC Institute of Public Goods and Policies between August and November 2014. 


\section{REFERENCES}

Acosta, M., Coronado, D., Leon, M.D. and Marin, M.R. (2005). Determining factors of patent generation in Andalucia (Spain) - Does public policy support technological knowledge generation in universities? ERSA conference papers ersa05p269, European Regional Science Association.

Acosta, M., Coronado, D., Leon, M.D. and Martinez, M.A. (2009). Production of university technological knowledge in European regions: Evidence from patent data. Regional Studies 43(9): 1167-1181.

Arqué-Castells, P., Cartaxo, R., García-Quevedo, J. and M. Godinho (2016). Royalty sharing, effort and invention in universities: Evidence from Portugal and Spain. Research Policy 45: $1858-1872$.

Azagra-Caro, J. M., Fernandez de Lucio, I. and Gutierrez, A. (2003). University patents: output and input indicators ... of what? Research Evaluation 12(1): 5-16.

Azagra-Caro, J. M., Carayol, N. and Llerena, P. (2006a). Patent production at a European research university: exploratory evidence at the laboratory level. The Journal of Technology Transfer, 31(2): 257-268.

Azagra-Caro, J.M., Yegros-Yegros, A., and Archontakis, F. (2006b). What do university patent routes indicate at regional level? Scientometrics 66 (1): 219-230.

Baldini, N. (2008). Negative effects of university patenting: Myths and grounded evidence. Scientometrics 75(2): 289-311.

Breschi, S., Lissoni, F. and Montobbio, F. (2008). University patenting and scientific productivity: a quantitative study of Italian academic inventors. European Management Review 5(2): 91-109.

Caine, M. (2003). Why and How the PCT is Used - Advantages and Problems. Available at: http://www.aipla.org/resources2/intlip/Documents/AIPLA\%20Documents/PCT_Caineppr.pdf

Cartaxo, R.M. and M. Mira Godinho (2017). How institutional nature and available resources determine the performance of technology transfer offices, Industry and Innovation, forthcoming, available online: DOI: 10.1080/13662716.2016.1264068

Ciaramella, L., Martínez, C., and Y. Ménière (2017). Tracking patent transfers in different European countries: methods and a first application to medical technologies. Scientometrics, 112:817-850.

Coronado, D., Acosta, M. and Fernandez, A.M. (2008). Attitudes to innovation in peripheral economic regions. Research policy 37(6): 1009-1021.

Coronado, D., Acosta, M. and Leon, M.D. (2004). Regional planning of R\&D and sciencetechnology interactions in Andalucia: a bibliometric analysis of patent documents. European Planning Studies 12(8): 1075-1095.

Coupe, T. (2003). Science is golden: academic R\&D and university patents. The Journal of Technology Transfer 28(1): 31-46.

Crespi, C., Geuna, A. and L. Nesta (2005). Labour Mobility of Academic Inventors. Career decision and knowledge transfer. SPRU Electronic Working Paper Series, N. 139, University of Sussex, Brighton, http://www.sussex.ac.uk/spru/1-6-1-2-1-36.html.

De Rassenfosse, G., Dernis, H., Guellec, D., Picci, L. and Van Pottelsberghe de la Potterie, B (2013). The worldwide count of priority patents: A new indicator of inventive activity. Research policy 42(3): 720-737.

De Rassenfosse, G. and B. Van Pottelsberghe de la Potterie (2013). The role of fees in patent systems: Theory and evidence. Journal of economic surveys 27(4): 696-716.

Del Barrio-Castro, T. and Garcia-Quevedo, J. (2009). The determinants of university patenting: Do incentives matter?. Working Papers 2009/13, Institut d'Economia de Barcelona (IEB).

Della Malva, A., Lissoni, F. and Llerena, P. (2013). Institutional change and academic patenting: French universities and the Innovation Act of 1999. Journal of Evolutionary Economics 23(1): 211-239. 
Dernis, H. and Kahn, M. (2004). Triadic patent families methodology. STI working paper 2004/2, Organisation for Economic Co-operation and Development, Paris, France.

Du Plessis, M., Van Looy, B., Song, X and T. Magerman (2009). Data Production Methods for Harmonized Patent Indicators: Assignee sector allocation. EUROSTAT Working Paper and Studies, Luxembourg.

European Commission (2015). Patent costs and impact of innovation. Brussels (available at http://ec.europa.eu/research/innovation-union/pdf/patent_cost_impact_2015.pdf)

Fernández-Sánchez, R. (2014). Valoración de patentes y toma de decisiones en una OTRI universitaria. Propuesta para una evaluación cualitativa. Tesina de Máster. Máster en Gestión de la Ciencia y la Innovación. Ingenio CSIC-UPV. Universidad Politécnica de Valencia.

Fernández-Sánchez, R. and Orellana-Muñoz (2016). Valoración de patentes y toma de decisiones en una OTRI universitaria. Propuesta para una evaluación cualitativa. Presentation at the Intenational Conference of RedUE-ALCUE, Granada, 26-28 October 2016.

Franzoni, C. and Scellato, G. (2011). Academic patenting and the consequences for scientific research. Australian Economic Review 44(1): 95-101.

Frietsch, R. and Jung, T. (2009). The internationalisation of international co-inventions, http://doku.iab.de/fdz/events/2009/Frietsch_Jung.pdf

Frietsch, R. and U. Schmoch (2010). Transnational patents and international markets. Scientometrics 82(1): 185-200.

García Aracil, A., Castro-Martínez, E., Azagra-Caro, J.M., D' Este, P. and I. Fernández de Lucio (2016), University technology transfer: the case of Spain, chapter in University Technology Transfer. The globalization of academic innovation.Ed: S.M. Bretznitz y H. Etkowitz, Oxon: Routledge.

Garcia-Quevedo, J. (2010). Incentivos de los academicos para patentar, in Sanz, L., Castro, L (coord.), Analisis sobre ciencia e innovacion en España, Federacion Española de Ciencia y Tecnologia (FECYT), Madrid.

Gaessler, F. (2016), Enforcing and trading patents. Evidence for Europe, Springer Gabler, Wiesbaden.

Geuna, A. and Nesta, L. J. (2006). University patenting and its effects on academic research: The emerging European evidence. Research policy 35(6): 790-807.

Geuna, A. and Rossi, F. (2011). Changes to university IPR regulations in Europe and the impact on academic patenting. Research Policy 40 (8): 1068-1076

Gonzalez-Albo Manglano, B. and M. A. Zulueta Garcia (2007). Normativas sobre patentes en las universidades españolas. Ciência da Informação 36: 69-78.

Graham, S. and Marco, A. and Myers, A. (2015). Patent Transactions in the Marketplace: Lessons from the USPTO Patent Assignment Dataset Georgia Tech Scheller College of Business Research Paper No. 29. Available at SSRN: http://ssrn.com/abstract=2696147 or http://dx.doi.org/10.2139/ssrn.2696147

Guasch, L. M. (2007). Nuevas perspectivas en la evaluacion de las patentes como parte del curriculum cientifico. Revista española de documentacion cientifica 30(2): 218-240.

Guellec, D. and B. van Pottelsberghe de la Potterie (2007). The Economics of the European Patent System. Oxford, Oxford University Press.

Henderson, R., Jaffe, A., and M. Trajtenberg (1998), Universities as a source of commercial technology: A detailed analysis of university patenting, 1965-1988, Review of Economics and Statistics, 119-127

Hidalgo, A. and G. Penas (2010). Las ayudas a la extension de patentes españolas como mecanismo de apoyo a la internacionalizacion de la tecnologia. Direccion $y$ Organizacion (38): 21-35.

Kamiyama, S., J. Sheehan and C. Martinez (2006).Valuation and Exploitation of Intellectual Property, OECD Science, Technology and Industry Working Papers, 2006/05, OECD Publishing. 
Lach, S. and M. Schankerman (2008). Incentives and invention in universities. The RAND Journal of Economics 39(2): 403-433.

Lemley, M. A. (2008). Are universities patent trolls. Fordham Intellectual Property Media and Entertainment Law Journal 18 (3): 611-631.

Lissoni, F. (2013), Academic Patenting in Europe: A Reassessment of Evidence and Research Practices, Industry and Innovation, 20(5): 379-384.

Lissoni, F., Llerena, P., McKelvey, M. and Sanditov, B. (2008). Academic patenting in Europe: new evidence from the KEINS database. Research Evaluation 17(2): 87-102.

Lissoni, F. and F. Montobbio (2015). The ownership of academic patents and their impact. Evidence from five European countries. Revue économique, Presses de Sciences-Po, 66(1):143-171.

Lissoni, F., Montobbio, F. and Zirulia, L. (2013). Inventorship and authorship as attribution rights: An enquiry into the economics of scientific credit. Journal of Economic Behavior \& Organization 95: 49-69.

MacLeod, C., Tann, J., Andrew, J. and Stein, J. (2003). Evaluating inventive activity: the cost of nineteenth-century UK patents and the fallibility of renewal data. The Economic History Review 56(3): 537-562.

Markman, G. D., Gianiodis, P.T., Phan, P.H. and D. B. Balkin (2005). Innovation Speed: Transferring University Technology to Market, Research Policy, 34: 1058-1075.

Martinez, C. (2009). Patenting chemical inventions in Spain. Chemistry Today, 25(5): 6-8.

Martinez, C. (2011).Patent families: when do different definitions really matter? Scientometrics, 86(1): 39-63.

Martinez, C., Azagra-Caro, J. and S. Maraut (2013), Academic inventors, scientific impact and the institutionalization of Pasteur's quadrant in Spain, Industry and Innovation, 2013,20 (5), 438-455.

Martinez, C. and S. Maraut (2014), Identifying author-inventors from Spain: methods and a first insight into results, Scientometrics, 101(1): 445-476.

Martinez, C. and V. Sterzi (2016). University patenting and the quest for technology transfer policy models in Europe, mimeo

Ménière, Y., Dechezleprêtre, A., and H. Delcamp (2012). Le marché des brevets français. Une analyse quantitative des cessions à partir des inscriptions dans le Registre national et le Registre européen des brevets. Rapport d'étude réalisée pour l'INPI

Mowery, D. C. (2004). Ivory tower and industrial innovation: university-industry technology transfer before and after the Bayh-Dole act in the United States, Stanford University Press.

Mowery, D. and B. Sampat (2005). The Bayh-Dole Act of 1980 and University-Industry Technology Transfer: A Model for Other OECD Governments? Journal of Technology Transfer, 30:115-127.

OCDE (2009). OCDE Patent Statistics Manual. OECD, Paris.

OCDE (2003). Turning Science into Business: Patenting and Licensing at Public Research Organisations, OECD, Paris.

Payne, A. A. and A. Siow (2003). Does federal research funding increase university research output? Advances in Economic Analysis \& Policy 3(1).

Peeters, C. and B. van Pottelsberghe de la Potterie (2006).Innovation strategy and the patenting behavior of firms. Journal of Evolutionary Economics 16(1-2): 109-135.

Peñasco, C., Martínez, C. and P. del Río (2016), Patentes "verdes" españolas solicitadas en la Oficina Europea de Patentes: características y cambios de propiedad. Instituto de Políticas y Bienes Públicos (IPP) CSIC, Working Paper. 2016-04

Pinto, H. and P.M. Rodrigues (2010). Knowledge production in European regions: the impact of regional strategies and regionalization on innovation. European Planning Studies 18(10): 1731-1748.

Putnam, J. (1996). The value of international patent rights. PhD thesis, Yale University 
Romero de Pablos, A. and J.M. Azagra-Caro (2009). Internationalisation of patents by Public Research Organisations from a historical and an economic perspective. Scientometrics 79(2): 329-340.

Ramos-Vielba, I., Fernández-Esquinas, M. and E. Espinosa de los Monteros (2010). Measuring university-industry collaboration in a regional innovation system. Scientometrics. 84: 649-667.

Represa-Sánchez, D., Castro-Martínez, E. and I. Fernández-de-Lucio (2005) Encouraging Protection of Public Research Results in Spain, Journal of Intellectual Property Rights, 10: 382-388

Sampat, B. N., Mowery, D. C. and A.A. Ziedonis (2003). Changes in university patent quality after the Bayh-Dole act: a re-examination. International Journal of Industrial Organization 21(9): 1371-1390.

Saragossi, S. and B. van Pottelsberghe de la Potterie (2003). What patent data reveal about universities: the case of Belgium. The Journal of Technology Transfer 28(1): 47-51.

Serrano, C. (2010) The dynamics of the transfer and renewal of patents. The RAND Journal of Economics, 41: 686-708.

Smith, G.V. and R.L. Parr (2000), Valuation of Intellectual Property and Intangible Assets Third Edition, John Wiley \& Sons, New York.

Squicciarini, M., Dernis, H. and Criscuolo, C. (2013). Measuring patent quality: Indicators of technological and economic value, OECD, Paris.

Sterzi, V. (2013). Patent quality and ownership: An analysis of UK faculty patenting. Research policy 42(2): 564-576.

Thursby, J. and M. Thursby (2003). University Licensing and the Bayh-Dole Act, Science 301: 1052.

Thursby, J. and M. Thursby (2007). Patterns of research and licensing activity of science and engineering faculty. Science and the University, Madison: University of Wisconsin Press, forthcoming.

Van Zeebroeck, N. (2011). The puzzle of patent value indicators. Economics of Innovation and New Technology 20(1): 33-62.

van Zeebroeck and van Pottelsbergue (2011) Filing strategies and patent value. Economics of Innovation and New Technology. 20(6): 539-561.

Walsh, J., Cho, C. and W. Cohen (2005). View from the Bench: Patents and Material Transfers, Science, 309 (5743): 2002-2003

Zuniga P, and D. Guellec D. (2009). Who licenses out patents and why? Lessons from a business survey. OECD STI Working Paper 2009/5.

Zucker, L., Darby, M., and M. Brewer (1998) Intellectual Human Capital and the Birth of U.S. Biotechnology Enterprises, American Economic Review, 88 (1): 290-306 
ANNEX 1

Table A1. Patent families filed by Andalusian public universities with priority 2003-2009

\begin{tabular}{lccccc}
\hline Variable & Obs & Mean & Std. Dev. & Min & Max \\
\hline Priority year & 444 & 2006.365 & 2.007262 & 2003 & 2009 \\
PCT international phase & 444 & .6396396 & .4806465 & 0 & 1 \\
PCT national phase & 444 & .1103604 & .3136919 & 0 & 1 \\
Family size & 444 & 1.324324 & 1.26357 & 1 & 14 \\
Licensing agreement & 444 & .1463964 & .3539019 & 0 & 1 \\
Citations received in 5 years & 444 & .3671171 & .986546 & 0 & 7 \\
Total citations received & 444 & .6418919 & 1.698533 & 0 & 14 \\
No citations received in 5 years & 444 & .8063063 & .3956374 & 0 & 1 \\
No citations received & 444 & .7432432 & .4373368 & 0 & 1 \\
OEPM substantial examination & 444 & .2072072 & .4057625 & 0 & 1 \\
Granted at OEPM & 444 & .9954955 & .0670398 & 0 & 1 \\
Nb of university professors & 444 & 1610.313 & 797.0915 & 106 & 2559 \\
Nb of families filed previous year & 444 & 11.30856 & 6.159052 & 0 & 22 \\
Royalty share for the inventor and research group & 444 & 60.54054 & 13.83719 & 50 & 90 \\
TTO age & 444 & 16.57432 & 2.948216 & 3 & 21 \\
Chemicals & 444 & .5698198 & .4956597 & 0 & 1 \\
Instruments & 444 & .3018018 & .4595575 & 0 & 1 \\
Electrical engineering & 444 & .1554054 & .3626994 & 0 & 1 \\
Mechanical engineering & 444 & .1013514 & .3021338 & 0 & 1 \\
Other & 444 & .0900901 & .2866338 & 0 & 1 \\
\hline$\quad$ Note: The number of citations received (in five years from publication and in total, as in Patstat April
\end{tabular}
2014) is calculated by adding up all the patent citations received by family members. 
Table A2. Patent families filed by Andalusian universities with priority 2003-2009, correlations

\begin{tabular}{|c|c|c|c|c|c|c|c|c|c|c|c|}
\hline & 1 & 2 & 3 & 4 & 5 & 6 & 7 & 8 & 9 & 10 & 11 \\
\hline 1 - PCT international phase & 1.0000 & & & & & & & & & & \\
\hline 2 - PCT national phase & $0.2644 *$ & 10000 & & & & & & & & & \\
\hline 3 - Family size & $0.1929 *$ & $0.7296 *$ & 1 & & & & & & & & \\
\hline 4 - Licensing agreement & $0.2312 *$ & $0.2811 *$ & $0.2722 *$ & 1 & & & & & & & \\
\hline 5 - Citations received in 5 years & $0.2177 *$ & $0.3721 *$ & $0.3171^{*}$ & $0.3048^{*}$ & 1 & & & & & & \\
\hline 6 - OEPM substantial examination & 0.0249 & -0.0027 & -0.0301 & -0.0702 & 0.0182 & 1 & & & & & \\
\hline 7 - Granted at OEPM & -0.0505 & 0.0237 & 0.0173 & 0.0279 & -0.0091 & 0.0344 & 1 & & & & \\
\hline 8- $\mathrm{Nb}$ of university professors & $0.1352 *$ & 0.0804 & $0.0953 *$ & 0.0691 & 0.0855 & $0.1124 *$ & 0.0824 & 1.0000 & & & \\
\hline 9- $\mathrm{Nb}$ of patent families filed previous year & $0.1566^{*}$ & 0.0828 & 0.0622 & 0.0579 & 0.0798 & $0.1135^{*}$ & $0.0963 *$ & $0.8500 *$ & 1 & & \\
\hline 10 - Royalty share for inventor and research group & 0.0599 & 0.0148 & -0.0262 & 0.0069 & -0.0063 & -0.0321 & -0.0460 & $-0.4295 *$ & $-0.4013 *$ & 1 & \\
\hline 11 - TTO age & $0.2451 *$ & -0.0052 & 0.0087 & -0.0699 & 0.0042 & $0.2683^{*}$ & 0.0588 & $0.4946 *$ & $0.4759 *$ & $0.1672 *$ & 1 \\
\hline
\end{tabular}

Note: * indicated significant at $5 \%$. In bold when pairwise correlation is higher than 0.4 in absolute value. 


\section{ANNEX 2: The PCT Route}

According to The Spanish Law of Patents (1986), Article 122.1, inventions made in Spain may not be applied for in any foreign country until two months have elapsed after the patent has been filed at the OEPM, unless the applicants counts with prior authorization. Whether this rule is applied or not by all Spanish inventors is an empirical question, so we checked in Patstat for the different filing strategies followed by the 3219 priority patents filed by Spanish public universities in 1998-2009, without imposing any restriction on the patent office of such priority filing, and found that $96.3 \%$ were national priorities filed at OEPM, 1.6\% were EPO priorities (filed directly at EPO), $0.8 \%$ were PCT priorities filed at OEPM (without a national priority filed earlier), $0.4 \%$ were Euro-PCT priorities filed at EPO (without a national priority). The rest, adding up to the remaining $0.9 \%$, were national priorities in foreign offices (USPTO, France, Brazil, Portugal, etc). The proportion of national priorities is even higher when we focus on the share of $19 \%$ of those filings made by the nine public universities of Andalusia that are the focus of our statistical analysis: $99.3 \%$ had a national priority, the remaining $0.7 \%$ had a PCT priority filing at OEPM. Thus, the PCT route that starts with the national priority is certainly the most common for Spanish public universities.

Spanish applicants can use the PCT route to file international extensions to national patents since 1989, when the country joined the PCT. The benefits of using the PCT route are multiple. First of all, the PCT procedure is a way to "buy time" that allows applicants to better assess the commercial potential of their inventions (Frietsch et al., 2012) and to find licensors which can provide financial resources to pay the national filing fees (Caine, 2003). All patent applicants have up to 12 months (priority year) to decide whether or not to extend their national final filing via the PCT route to other countries. In terms of cost, applicants pay a single modest fee for all designated countries between the $12^{\text {th }}$ and $13^{\text {th }}$ month after the first filing, postponing 18 months the payment of national fees, which are more expensive. Another advantage is that by a single filing of a PCT application made with a patent office officially designated by WIPO as PCT Receiving Office, applicants initiate procedures for seeking protection to their inventions in 151 countries at the same time. Four months later they receive the PCT Search Report and the written opinion from the PCT International Search Authority. The international publication of the filing happens in the 18th month from the priority filing. The national phase begins in the 20th month and finishes the 30th month (31th month some countries).

The OEPM is a PCT receiving office ${ }^{44}$ and is thus responsible for doing the PCT search between the 13th and 16th month. ${ }^{45}$ There is an amendment claim period ${ }^{4}$ for applicants

\footnotetext{
44 International Searching and International Preliminary Examining Authorities under the PCT,
} http://www.wipo.int/pct/en/access/isa_ipea_agreements.html 
between the 16th and the 18th month, but if they do not want to amend their applications they can decide about national phase entries from the 16th month. Spanish applicants using the PCT route have to pay three different fees: (i) first feeling fees (Spanish universities are exemptOrganic Law of Universities 6/2001); (ii) PCT fees (universities are exempt of international searching fees according to Organic Law of Universities 6/2001 (1875 euros) and they only have to pay transmission fees $(74,99$ euros), transmission fees for the priority document $(29,99$ euros in 2015) and international filing fee - up to 30 pages- (1,097 euros), each subsequent sheet from 31 (12 euros); (iii) national phase entry fees, which are the most expensive and are indicated for all countries in their National Chapter in the webpage of WIPO. Figure A2 below describes the PCT timeline for an applicant that applies for an international extension following a national first filing. Most of the Spanish patent filings that pursue the PCT procedure beyond the international phase tend to seek regional protection in Europe by entering the regional phase at EPO (with a so-called Euro-PCT application), ${ }^{46}$ in addition to seeking national protection in other offices outside Europe.

Lastly, it is worth noting that between 2003 and 2012, OEPM granted subsidies to cover patenting costs from filing foreign patent applications. ${ }^{47}$ The call required the applicant to have a national patent or utility model filed at OEPM or a PCT application filed at the OEPM as receiving office under the PCT Treaty. This support was mainly thought for small and medium enterprises. Public universities and public research organizations could also apply and they did, but they represented only a small share of the beneficiaries. ${ }^{48}$ Hidalgo and Penas (2010) show that among all institutions benefiting from the OEPM subsidies granted in 2003-2006, $16 \%$ were filed by universities and public research public organizations (mainly in the areas of human necessities, chemistry and physics), $64 \%$ by firms, $17 \%$ by individual inventors and $3 \%$ by technology centers. Andalusia concentrated $4 \%$ of all applications for subsidies in those years (27 applications and only 7 of them from universities and public research organizations).

\footnotetext{
${ }^{45}$ OEPM has the status of ISA since year 1995. It is one of the few patent offices in the world to be qualified to perform the international search report. By 2 May 2015, there were eighteen ISAs. http://www.oepm.es/cs/OEPMSite/contenidos/NORMATIVA/NormasSobrePatentes_MU_Topografias_ CCP/NSPMTCCP_InternacionalesPatentes/Real_Decreto_1123_1995_de_3_de_julio.htm

4 In the "amendment claim period" applicants could submit a replacement sheet containing a complete set of claims in replacement of all the claims originally filed (Regulations under the PCT- Rule 46.5a). http://www.wipo.int/pct/en/texts/rules/r46.htm

${ }^{46}$ The unitary patent had not been implemented yet in the period we analyse.

${ }^{47}$ The Spanish Official Gazette has only published the patent numbers linked to these OEPM subsidies for the year 2006, for the rest of the years it only publishes the name of the institution receiving it and the number of the subsidy application dossier.

${ }^{48}$ All applications filed not earlier than 2003 were eligible. All private companies could apply between 2006 and 2012, and from 2012 onwards only small and medium enterprises remained eligible.
} 


\section{Figure A2. Filing international extensions of a Spanish national priority via PCT}

M1.T1-M1.T

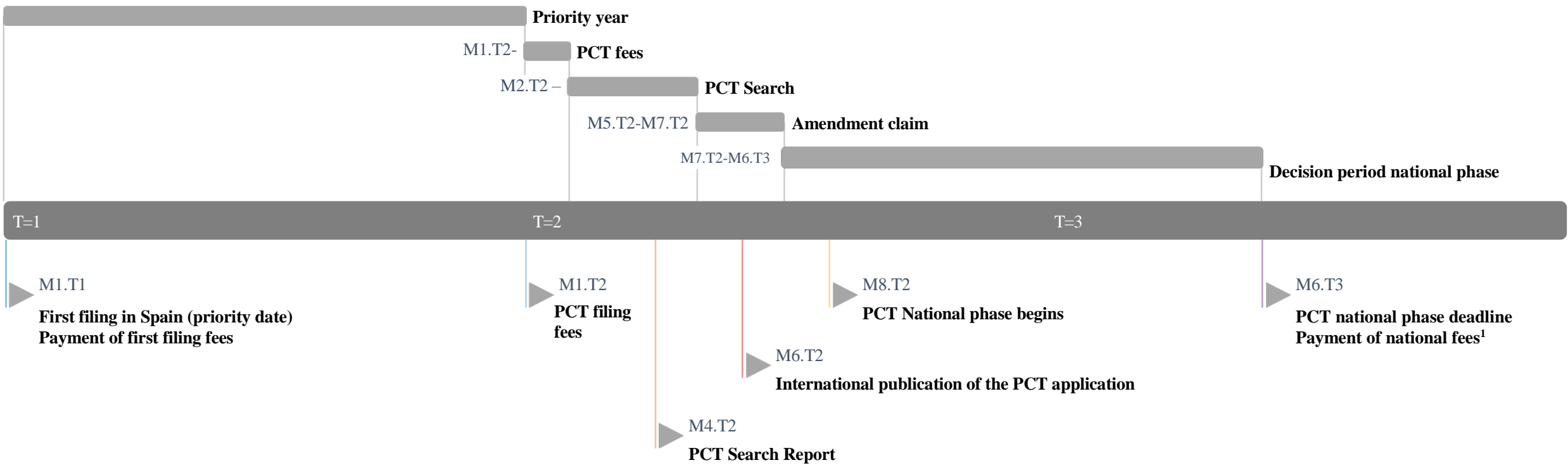

Notes: (1) National phase entry fees are indicated in each National Chapter (Summary and fees annex) See http://www.wipo.int/pct/en/appguide . More information available at: http://www.ip-coster.com/IPCoster.aspx

Source: Own elaboration based on information available from WIPO and EPO. http://www.epo.org/applying/international/guide-for-applicants/html/e/ga aiii.htm http://www.wipo.int/export/sites/www/pct/es/seminar/basic 1/timeline.pd 